\title{
IFRS Adoption, Legal Systems and the Voluntary Disclosure of Human Capital: Cross-country Evidence from the Banking Industry
}

\author{
Mohamed A. Elbannan ${ }^{1}$ \\ ${ }^{1}$ Department of Accounting, Faculty of Commerce, Cairo University, Orman, Giza 12613, Egypt \\ Correspondence: Mohamed A. Elbannan, Department of Accounting, Faculty of Commerce, Cairo University, \\ Orman, Giza 12613, Egypt. \\ Received: May 9, 2016 \\ doi:10.5430/afr.v5n4p30 \\ Accepted: June 29, 2016 \\ Online Published: July 15, 2016 \\ URL: http://dx.doi.org/10.5430/afr.v5n4p30
}

\begin{abstract}
This study examines the value relevance of voluntary human capital disclosures by banks and the effect of the adoption of International Financial Reporting Standards (IFRS) on the value relevance of these disclosures. Human capital disclosures allow capital market participants to evaluate the intellectual capital of the disclosing banks, which in theory may enable market participants to assess the competitiveness of the bank's human resource strategy and the productivity of the workforce vis-à-vis benchmark performance. While IFRS does not mandate particular form of voluntary human capital disclosures (VHCD), VHCD is expected to possess information content that is useful to market participants in their equity pricing decisions. The study is conducted using a cross-country sample of 10,199 bank-years that reported labor costs. Market participants, however, are found to relate VHCD negatively to prices and returns in common and civil law countries alike. Results also suggest that IFRS adoption reduces the value relevance of VHCD due to the abundance of alternative information provided under the more comprehensive IFRS framework that helps in the prediction of future cash flows. Finally, market participants find VHCD value relevant after IFRS adoption in common law countries potentially because it reduces uncertainty about an important determinant of the bank's future performance. On the other hand, market participants in civil law countries view VHCD as value relevant but coming at added time and financial investment. As an application of the results to an emerging economy, the implications for the Egyptian accounting profession, banking sector and capital markets are discussed.
\end{abstract}

Keywords: Human capital accounting, Voluntary disclosure, IFRS, Value relevance, Egypt

\section{Introduction}

The purpose of this study is to examine the value relevance of voluntary human capital disclosures and the effect of the adoption of International Financial Reporting Standards (IFRS) on the value relevance of these disclosures. Numerous countries seeking to increase inflows of international investment capital into their companies have adopted IFRS in the belief that these standards increase the decision usefulness of publicly available financial information compared to national accounting standards and hence facilitate more informed equity valuation (Ball, 2006; Nobes \& Parker, 2004). Firms in several countries were required to shift from applying national accounting standards to IFRS over the past two decades. The mandatory adoption of IFRS in these countries met with some initial resistance due to the fact that national accounting standards mostly originate from tax codes or reflect national characteristics and hence reflect national characteristics. However, the cost of IFRS adoption, including surrendering elements of "national sovereignty", were offset by the myriad benefits, including stronger integration into an increasingly globalized capital markets (Barth, Landsman, \& Lang, 2008).

IFRS, however, has met its own share of criticism. Extant research on the incremental value relevance of reported earnings and equity before and after adoption is mixed and conflicting. The mixed results may be attributed to IFRS's lack of capturing of significant value-generating phenomena associated with earnings and equity, such as human capital. This study investigates this proposition in the context of the value relevance of human capital-based information (Samudhram, Shanmugam, \& Low, 2008; Vafaei, Taylor, \& Ahmed, 2011). Current IFRS does not require the recognition of this information despite empirical evidence to its usefulness to capital market participants (Verma \& Dewe, 2004; 2008). Prior research is mixed on the value relevance of voluntary disclosures in various settings and using different measurements. Whereas Lajili and Ze'ghal (2005, 2006), Lapointe-Antunes, Cormier, and Magnan (2006) and Gamerschlag (2013) examine voluntary human capital disclosures (VHCD) and find that these disclosures are value relevant especially in their long-term price effects, Hassel, Nilsson, and Nyquist (2005) and Banghøj and Plenborg 
(2008) find that additional voluntary disclosures do not enhance the association between present and future earnings, suggesting that investors may have difficulties in integrating voluntary disclosures in firm valuation. In view of these mixed results, further research on the value relevance of additional disclosures, particularly VHCD, is needed.

Accountants do not consider human capital as an earning asset, maintaining instead their traditional focus on accounting for the firm's observable assets. Prudence motivates this traditional approach to avoid overstating assets and earnings, because accounting numbers are used to write and complete contracts such as debt and compensation contracts. However, human capital disclosures allow capital market participants to evaluate the intellectual capital of the disclosing banks. The growth opportunities available to a bank are partially dependent on how much intellectual capital (and human resources are at the center of this capital) the bank possesses. Providing information on the bank's human capital voluntarily in theory may enable market participants to assess the competitiveness of the bank's human resource strategy and the productivity of the workforce vis-à-vis benchmark performance. While IFRS does not mandate particular form of VHCD, it is expected that VHCD would possess information content that is useful to market participants in their equity pricing decisions. It is also expected that mandatory IFRS adoption would reduce the usefulness of VHCD, primarily because of the wealth of information reported under these high quality standards.

To test the hypotheses, the value relevance of VHCD from 1998 to 2013 is examined in a number of countries that adopt IFRS during this timeframe. In order to conduct this investigation, a sample of 10,199 cross-country bank-year observations is generated. The study examines whether VHCD are value relevant by running a regression of stock prices on labor costs and a vector of control variables. The study uses labor costs reported by banks as proxy for VHCD and assess value relevance of VHCD using price and returns model specifications. The results suggest that market participants consider VHCD to be value relevant and incorporate changes in labor cost information into their pricing decisions, regardless of the legal system a bank is subject to (common or civil law countries). Market participants, however, are found to relate VHCD negatively to prices and returns. Potentially, these participants are concerned with competitive consequences of such disclosures or operating efficiency issues. Results also suggest that IFRS adoption reduces the value relevance of VHCD due to the abundance of alternative information provided under the more comprehensive IFRS framework that helps in the prediction of future cash flows. Finally, market participants find VHCD value relevant after IFRS adoption in common law countries potentially because it reduces uncertainty about an important determinant of the bank's future performance. On the other hand, market participants in civil law countries view VHCD as value relevant but coming at added time and financial cost.

This study makes contributions to at least three major streams of literature: human capital disclosures, IFRS, and value relevance of financial information. First, within the literature on human capital accounting, this is the first study to present empirical evidence based on a cross-country sample of 27 nations that recently fully adopted IFRS. Most human capital studies focus on individual nations (such as, Lajili and Zeghal (2005) who use a U.S. sample and Samudhram et al. (2014) who use a Malaysian sample) and hence their results may be affected by country-specific regulatory, economic or other factors. Second, within value relevance literature, this is the first empirical study to examine the usefulness of VHCD in an IFRS-based regime, extending prior research covering developed markets. Thirdly, it indicates that voluntary disclosures may be employed to overcome the limitations of IFRS, and disclose intangible assets to shed light on the bank-specific strengths. The next section discusses the background and motivation for this study, and develops the hypotheses. Section 3 describes the data, presents model specifications, and descriptive statistics. Section 4 presents the results and discusses the findings. Section 5 presents results of additional analysis. Section 6 discusses the implications for the Egyptian accounting profession, banking sector and capital markets, and concludes.

\section{Literature Review and Hypotheses Development}

\subsection{Authoritative Literature on Human Capital Accounting}

IFRS 2 and IAS 19 govern required accounting treatment for labor cost and require firms to disclose their expenditures on salaries, wages, employee benefits and executive compensation. More specifically, IFRS 2, Share-based Payments, governs whether firms should capitalize or expense labor services received in exchange for shares or share options granted to employees based on certain recognition criteria. Further, IAS 19, Employee Benefits, requires firms to charge employee benefits as expenses.

These standards mostly mandate the expensing, rather than capitalization, of labor costs on the grounds that recording expenditures whose future economic benefits may be uncertain or unrealizable overstates assets and earnings. Since the contractual obligations, such as executive compensation, of a bank are based on these accounting numbers, a bank's obligations are likely to be volatile. However, these standards, along with all other IFRSs, do not mandate the disclosure of labor costs as a separate line item in the financial statements. Firms that provide this information voluntarily tend to disclose the amounts in the notes accompanying the statements rather than in the body of the statements. Nevertheless, 
these firms do not decompose this information into its basic components such as benefits and incentive compensation (Ballester, Livnat, \& Sinha, 2002).

\subsection{Value Relevance of Voluntary Human Capital Disclosures}

The value relevance of voluntary disclosures may be defined as the degree of correspondence between reported information and market indicators (Beaver, 2002; Ettredge, Soo Young, Smith, \& Zarowin, 2005). Studies examining value relevance of accounting information typically employ a variation of the Ohlson (1995) residual income model. Based on the clean surplus and present value of expected dividends assumptions, the model basically links the market value with the book value of equity, earnings, and other variables of interest (Hassel et al., 2005; Lapointe-Antunes et al., 2006). In general, the evidence on the value relevance of voluntary disclosures is mixed. For example, Lapointe-Antunes et al. (2006) use the Ohlson (1995) model in conjunction with accounting variables and discretionary accruals in a Swiss sample and conclude that these disclosures are valuable to investors when making equity valuation decisions. In contrast, Hassel et al. (2005) finds that increased disclosures pertaining to Swedish firms' environmental impact are negatively associated with market value, potentially because of the cost that companies incur to account and report on these matters. Banghøj and Plenborg (2008) also fail to find evidence that Danish firms' voluntary disclosures are useful in investors' equity valuation decision.

Prior studies evaluating the value relevance of VHCD in particular find mixed results (Flamholtz, 1999; Flamholtz, Bullen, \& Hua, 2002; Lajili \& Zeghal, 2005; 2006; Verma \& Dewe, 2004, 2008). Whereas several studies find VHCD value relevant, few others find that market participants fail to fully incorporate such information into their investment decision-making process. Bell et al. (2002) find that employee stock option-related costs are value relevant. Ballester et al. (2002) examine the proportion of U.S. labor costs that are relevant for investors. Furthermore, Abdel-Khalik (2003) finds that information on the managerial skills of executives is value relevant. Lajili and Zeghal (2005) finds that VHCD in U.S. firms are value relevant, but Lajili and Zeghal (2006) point to potential market failures in capturing signals from these disclosures. Other studies also find that human resource disclosures are related to higher firm performance in various areas (e.g. Wyatt, 2008). The provision of increased VHCD reduces information asymmetry between preparers and users of financial statements and improves the precisions future cash flows assessment (An, Davey, \& Eggleton., 2011; Bukh, 2003; Leuz \& Verrecchia, 2000; Healy \& Palepu, 2001; Lev, 2001; Van der Meer-Kooistra \& Zijlstra, 2001). These disclosures can inform users about the relative weight of the firm's labor expenditures in relation to revenues and other costs and the appropriateness of these expenditures in the context of the firm's industry and competitive strategy. Essentially, this information can trigger market disciplinary action that will improve resource allocation and reduce agency and transaction costs (Botosan, 1997; Botosan \& Plumlee, 2002; Healy \& Palepu, 2001).

The U.S. setting in most of these studies reduces the external validity of the findings for a number of reasons. The IFRS-based in other countries information setting is different from the GAAP-based U.S. setting used in Lajili and Zeghal (2005). Furthermore, prior research suggests that close to only 10 percent of U.S. listed firms consistently provide human capital disclosures (Ballester et al., 2002), which may reduce the generalizability of the study findings. The current paper extends these studies by incorporating human capital-based metrics into the Ohlson (1995) model to explore the value relevance of VHCD using a set of IFRS adopting banks as a cross-country setting. It is argued that capital market participants should find disclosure of labor cost to be an important indicator of the extent of a bank's commitment to its employees (as a primary stakeholder group) and hence to improved performance. When compared to banks that disclose their labor costs, banks that disclose these costs are implicitly conveying a greater commitment to its employee stakeholders. Labor unions and other concerned groups are in effect provided with information that they can use in negotiating labor contracts. This commitment is expected to be valued by investors. Therefore, the first hypothesis (H1) is stated in the alternate form as follows:

H1: Ceteris paribus, VHCD are not expected to be value relevant.

\subsection{IFRS and Value Relevance of VHCD}

In general, studies examining the economic consequences of IFRS adoption provide evidence that IFRS-based corporate disclosures are of higher quality than those provided under local accounting standards (Aharony, Barniv, \& Falk, 2010; Devalle, Onali, \& Magarini, 2010). They find that value relevance improves markedly in those countries where accounting practices diverge the most from IFRS and that the improvement is primarily in the value relevance of earnings but not the book value of equity. Other studies investigating the economic impact of IFRS adoption and found that it results in lower cost of equity (Daske, Hail, Leuz, \& Verdi, 2011; Kim \& Shi, 2010), higher market liquidity and trading volume (Leuz \& Verrecchia, 2000), higher earnings response coefficients and lower stock price synchronicity (Bartov, Goldberg, \& Kim, 2005), more favorable price and non-price terms in private debt contracting (Kim et al., 2011), and greater investment flows from attracting more foreign mutual funds (Covrig, DeFond, \& Hung, 2007). 
These studies suggest that IFRS adoption raises the quality of reported earnings because it increases accounting quality in the post-adoption period primarily because it limits managers' discretion, enhances more rigorous enforcement, results in less aggressive earnings management and more timely recognition of firm financial performance into financial statements (Aharony et al., 2010; Ball, 2006; Barth et al., 2008). In light of these studies demonstrating the positive impact of IFRS adoption on the information content of accounting information, it is expected that voluntary disclosures would be less useful in reducing information asymmetry and increasing transparency following the adoption of IFRS adoption. As argued in the first hypothesis, increased disclosures act to inform market participants where mandatory guidance is absent or does not fully meet market needs (e.g., the expensing rather than capitalization of R\&D (Lev \& Sougiannis, 1996). Therefore, in the presence of higher quality accounting guidance, the value relevance of voluntary disclosures, including VHCD, is expected to decline following adoption. Accordingly, the second hypothesis (H2) is stated in alternate form as follows:

$\mathrm{H} 2$ : Ceteris paribus, the value relevance of VHCD is likely to decrease following mandatory IFRS adoption.

\subsection{The Value Relevance of VHCD for Voluntary IFRS Adopters}

Prior to the mandatory IFRS adoption, many banks adopted IFRS voluntarily. Extant research examines the effects of voluntary adoption on a variety of variables of interest and suggests that voluntary IFRS adoption signals commitment on the part of the bank to higher quality reporting practices, thereby increasing analyst coverage of the firm (Ashbaugh \& Pincus, 2001; Bartov et al., 2005; Ding, Hope, Jeanjean, \& Stolowy, 2007; Kim \& Shi, 2011; Leuz \& Verrecchia, 2000). Moreover, analysts following these firms will use this improved set of publicly available accounting information to produce more precise earnings forecasts (Kim \& Shi, 2012). This richer information environment of voluntary IFRS adopters is expected to facilitate the incorporation of accounting information into stock prices and increase the value relevance of reported information. Similarly, the perceived higher credibility with which market participants view the financial information of voluntary IFRS adopters should increase the value relevance of complementary VHCD in comparison to non-IFRS adopters.

The situation is different for these voluntary adopters in the post-mandatory IFRS adoption period. Horton, Serafeim, and Serafeim (2011) find that voluntary adopters do not benefit significantly more from mandating IFRS compared to mandatory adopters, whose quality of information environment increases more significantly than that of voluntary adopters. Further evidence indicates that mandatory IFRS adoption increased within- and cross-country comparability of accounting information and made accounting information more useful for assessing performance for executive compensation, investment and financing decisions, and other purposes. For example, using voluntary adoption data, $\mathrm{Wu}$ and Zhang (2009) show that adoption of IFRS is associated with increases in the sensitivities of CEO turnover and employee layoffs to accounting earnings.

The evidence in the above studies points at accounting information acquiring more value relevance for voluntary adopters prior to the mandatory IFRS adoption. Once mandated, the IFRS requirements for high quality accounting information increases the transparency and reduces information asymmetries for banks that did not previously adopt IFRS. In this case, mandatory adopters match the incremental value relevance acquired by voluntary adopters prior to mandatory adoption. In the post-mandatory adoption period, VHCD provided by voluntary adopters appears relatively less useful in the context of the enriched information environment facilitated by the mandated standards. Market participants, e.g., analysts, were willing to price stock of firms providing VHCD at a premium because these disclosures were viewed as private information that has the potential to increase the precision of earnings forecasts. The emergence of IFRS as mandated standards reduces the perceived usefulness of VHCD because the high quality IFRS accounting requirements increases comparability across banks and increases the value relevance of accounting information of all adopting banks in a manner that puts all banks at a par. Since VHCD does not provide "news" about voluntary adopters, the value relevance of these disclosures is expected to decline in importance following the mandatory IFRS adoption. Accordingly, the third hypothesis (H3) is stated in alternate form as follows:

H3: Ceteris paribus, value relevance of VHCD reported by voluntary IFRS adopting banks is likely to be higher before the mandatory adoption year than after that year.

\section{Data and Research Design}

\subsection{Model Specification}

To test for the value relevance of labor costs, the contemporaneous year-end labor costs reported by a bank is used as a proxy for its VHCD. Labor costs are obtained from the Compustat Global Fundamentals Annual File. To test H1, the following regression equation is estimated and the coefficient on the labor cost ( $L B R$ (Note 1)) is used as a measure of the contemporaneous relation between stock prices (PRICE) or returns (RETURN) and labor costs: 


$$
\begin{aligned}
& (\text { Stock })_{i t}=\alpha_{0}+\alpha_{1} L B R_{i t}+\alpha_{2} B V_{i t}+\alpha_{3} E A R N_{i t}+\alpha_{4} S I Z E_{i t}+\alpha_{5} L V G_{i t}+\alpha_{6} G R O_{i t}+\alpha_{7} N E R N_{i t}+\alpha_{8} C V G_{i t}+Y_{D}+C_{D} \\
& +e_{i t} \quad . .
\end{aligned}
$$

Where all variables are as defined in Appendix A (Note 2). Model 1 is estimated using an OLS regression with data for the main results covering the years 1998-2013. Value relevance models typically are based on price or return model specifications, which show the effects of labor costs and their changes respectively on prices and change in these prices (Note 3). Model 1 measures the overall effects of labor costs on stock prices during the sample years. If investors recognize that labor costs is useful in making pricing decisions, then the coefficient of $L B R, \alpha_{l}$, will be significantly related to the stock prices and returns, and hence $\mathrm{H} 1$ would be statistically supported. Two possibilities exist with respect to the direction of the relation. First, $\alpha_{1}$ will be negative if investors associate labor costs with excessive, inefficient executive pay. Alternatively, $\alpha_{l}$ will be positive if investors believe that larger labor expense is money well spent; that is, a larger labor cost implies higher investment in human capital. However, the coefficient will be insignificant if investors do not find labor cost information to be decision-useful. Since labor costs involve cash outflows however, it is expected that the coefficient would have a negative sign. This means that higher labor expenditures are viewed as inefficient and unproductive.

Model 1 is tested as a fixed-effects model with time-independent effects for each entity that is possibly correlated with the regressors (Note 4) (Stock \& Watson, 2011). Furthermore, in order to control the size-related heteroscedasticity problem, the primary explanatory variable $(L B R)$ is deflated by the total number of outstanding common shares. Previous studies use deflators to reduce the spurious effect of scale differences, and commonly suggest number of shares outstanding as deflator to more effectively mitigate scale effects (Ahmed \& Falk, 2006; Barth \& Clinch, 2009). For the OLS regressions, the standard errors are clustered by bank and year.

The second model tests whether the mandatory IFRS adoption negatively affects the value relevance of labor cost. The following regression equation, which is based on Model 1, includes IFRS (a dummy variable coded 1 for years of and after IFRS mandatory adoption, 0 otherwise) and an interaction term $L B R^{*} I F R S$, which represents the interaction between IFRS and $L B R$ (labor costs). Model 2 is hence stated as follows:

$$
\begin{gathered}
(\text { Stock })_{i t}=\beta_{0}+\beta_{1} L B R_{i t}+\beta_{2} I F R S_{i t}+\beta_{3} L B R_{i t} * I F R S_{i t}+\beta_{4} B V_{i t}+\beta_{5} E A R N_{i t} \\
\beta_{9} N E R N_{i t}+\beta_{10} C V G_{i t}+Y_{D}+C_{D}+\zeta_{i t} \cdots \cdots E_{i t}+\beta_{7} L V G_{i t}+\beta_{8} S G R O_{i t}+ \\
\text { (Model 2) }
\end{gathered}
$$

Where all variables are as defined in Appendix A. The value relevance of labor cost is tested by examining the significance levels of the coefficient on the interaction term $\beta_{3}$. Note that IFRS refers to banks that adopted IFRS for the first time on or after the mandatory adoption date. As argued in the second hypothesis, mandatory IFRS adoption is expected to have a disruptive effect on the value relevance of $L B R$. Hence, empirical support would be rendered to $\mathrm{H} 2$ is the coefficient $\beta_{3}$ is insignificant, while $\beta_{l}$ is significantly negative. Similar to Model 1, Model 2 is tested as a fixed effects regression of stock prices and returns on IFRS, LBR, LBR $* I F R S$, and a vector of control variables. Although not hypothesized, the model also tests the effects of mandatory IFRS adoption on stock prices. Prior research examines the value relevance of mandatory IFRS adoption and finds supporting evidence for a positive relation (e.g., Armstrong et al., 2010). Therefore, a positive and significant sign for $\beta_{2}$ is expected.

Finally, the third model tests whether voluntary IFRS adopters have higher (lower) value relevance of VHCD before (after) mandatory adoption. Regression Model 3 includes VOL (a dummy variable coded 1 for banks voluntarily adopting IFRS before the mandatory adoption year, 0 otherwise) and interaction terms representing the two- and three-way interactions among $L B R, V O L$ and PREDUM. Hence, Model 3 is specified as follows:

$$
\begin{aligned}
& (\text { Stock })_{i t}=\gamma_{0}+\gamma_{1} L B R_{i t}+\gamma_{2} V O L_{i t}+\gamma_{3} \text { PREDUM }_{i t}+\gamma_{4} L B R_{i t} * V O L_{i t}+\gamma_{5} V O L_{i t} * \operatorname{PREDUM}_{i t}+\gamma_{6} L B_{i t}{ }^{*} \operatorname{PREDUM}_{i t} \\
& +\gamma_{7} L B R_{i t}{ }^{*} V O L_{i t} * P R E D U M_{i t}+\gamma_{8} B V_{i t}+\gamma_{9} E A R N_{i t}+\gamma_{10} S I Z E_{i t}+\gamma_{11} L V G_{i t}+\gamma_{12} G R O_{i t}+\gamma_{13} N E R N_{i t}+ \\
& \gamma_{14} C V G_{i t}+Y_{D}+C_{D}+\delta_{i t} \ldots \ldots \ldots
\end{aligned}
$$

Where all variables are as defined in Appendix A. Note that voluntary adopters are those banks adopting IFRS prior to the mandatory adoption date, and they remain designated as such after that date. As argued in the third hypothesis, it is expected that voluntary adopters see higher (lower) value relevance of VHCD before (after) the mandatory adoption. Accordingly, a negative and significant coefficient $\gamma_{7}$ would provide support to H3. Similar to Model 1, Model 3 is tested as a fixed effects regression of stock prices on explanatory and control variables.

A vector of control variables that are argued in the literature to affect stock prices is included in the model. Prior research, using the Ohlson (1995) value relevance model, controls for book value of equity and earnings, and hence this study includes those two variables ( $B V$ and $E A R N$, respectively) in the model. Additionally, bank size (SIZE) and incidence of negative earnings (NERN; e.g., Aharony et al., 2010; Oliveira, Rodrigues, \& Craig., 2010) are included in the model. The variable SIZE is expected to be positively related to stock price. On the other hand, the dummy representing the 
incidence of negative earnings (NERN) serves to control for changes in pay levels associated with negative performance. Prior studies suggest that firms generating losses tend to be valued differently than those generating income (Basu, 1997; Collins, Maydew, \& Weiss, 1997; Hayn, 1995). The variable NERN is expected to have a negative relation with stock price. Leverage $(L V G)$ is included as a control variable because it is a proxy for risk where debt holders may monitor the bank to ensure that management risk-taking behaviors are in line with debt holders' preferences. A negative relation is expected between $L V G$ and stock prices. Also, debt holders may be involved in monitoring and assessment of the fairness of fair labor practices. Collins et al. (1994) and Core, Guay, \& Buskirk (2003) argue that sales growth, as a proxy for firm growth opportunities, can serve to mitigate the lag in accounting information in reflecting economic events compared to market values that lead accounting numbers. Therefore, sales growth $(G R O)$ is included in the model and expected to have a positive association with price. Similarly, analyst coverage $(C V G)$ is controlled for because banks followed by more analysts can be more disciplined meeting earnings forecasts. A positive relation is expected between $C V G$ and stock prices.

\subsection{Sample and Data}

All 1,498 banks listed in the Compustat Bank file during the period 1998-2013 are used to compose the initial sample. Banks are eliminated based on the availability of stock data from the Compustat Security Monthly file and analyst coverage data from I/B/E/S. The remaining banks with data available on all three sources constitute the final sample of 1,498 banks (10,199 bank-years) across the 16-year test period from 27 countries. Table 1 shows the sample selection procedure.

Table 1. Sample selection procedure

\begin{tabular}{lrrrr}
\hline & Banks & $\%$ & Bank-years & $\%$ \\
\hline Banks from sample countries listed on Compustat Global & & & & \\
$\quad$ Fundamentals Bank File during 1998-2013 & 1,643 & 100.00 & 13,144 & 100.00 \\
Less: Banks lacking necessary financial data & $\underline{(122)}$ & $\underline{(7.43)}$ & $\underline{(736)}$ & $\underline{(5.60)}$ \\
Subtotal & 1,521 & 92.57 & 12,408 & 94.40 \\
Less: Banks with no available stock market data & $\underline{(23)}$ & $\underline{(1.40)}$ & $\underline{(2,209)}$ & $\underline{(16.81)}$ \\
Final sample for price specifications & 1,498 & 91.17 & 10,199 & 77.59 \\
Less: Data available for calculating returns & 0 & 0.00 & $(251)$ & $(1.91)$ \\
Final sample for return specifications & 1,498 & 91.17 & 9,948 & 75.68 \\
\hline
\end{tabular}

Table 2, Panel A, presents the descriptive statistics for the study variables. It shows that $L B R$ ranges from a minimum of -1.210 to a maximum of 3.420 with a mean of 0.704 . This indicates wide variation in the labor costs incurred by banks represented in the sample, possibly due to the differences in regulatory environments pertinent to labor practices in the sample countries. This variation implies a high degree of heterogeneity among sample banks in labor practices. Panel B reports the results of conducting Pearson (Spearman in the lower triangle) correlation coefficients among the study variables. $L B R$ is found to be significantly related to some of the variables, particularly SIZE, $L V G$, and NERN. The large correlations are expected since labor costs are bound to be affected by resources available to the banks. Such resources increase as banks become larger, have more access to debt financing, and less vulnerable to financial losses. Since OLS regression is essentially robust, the results of unreported multicollinearity tests do not show serious problems that indicate violations of regression assumptions. Panel C reports the number of observations, legal system, date of IFRS adoption (if any) and annual $L B R$ means for each of the 27 countries represented in the study. U.S. banks dominate the sample with almost 94 percent of total observations, possibly biasing the results. Some of the analyses are conducted separately for U.S. and non-U.S. firms to prevent this bias from contaminating the results. 
Table 2. Descriptive statistics and correlations

Panel A: Bank-level descriptive statistics

\begin{tabular}{llllllll}
\hline Variable & Mean & SD & Min. & Max. & 25 & 50 & 75 \\
\hline PRICE & 2.753 & 0.787 & 0.410 & 4.630 & 2.357 & 2.811 & 3.258 \\
RETURN & 0.044 & 0.370 & -0.790 & 1.550 & -0.170 & 0.022 & 0.226 \\
LBR & 0.704 & 0.730 & -1.210 & 3.420 & 0.276 & 0.707 & 1.103 \\
$B V$ & 2.577 & 0.606 & 0.840 & 4.970 & 2.226 & 2.563 & 2.892 \\
EARN & 1.133 & 0.773 & -1.220 & 3.830 & 0.725 & 1.165 & 1.557 \\
SIZE & 7.288 & 1.952 & 4.330 & 13.840 & 6.015 & 6.802 & 8.000 \\
LVG & 0.903 & 0.036 & 0.750 & 0.970 & 0.889 & 0.909 & 0.924 \\
GRO & 0.101 & 0.187 & -0.290 & 1.000 & -0.005 & 0.066 & 0.161 \\
NERN & 0.102 & 0.303 & 0.000 & 1.000 & 0.000 & 0.000 & 0.000 \\
CVG & 23.815 & 52.638 & 0.000 & 423.000 & 0.000 & 0.000 & 23.000
\end{tabular}

Panel A reports the bank-level descriptive statistics for key variables across the full sample of 10,199 observations representing 1,498 distinct banks from 27 economies during the period of 1998 to 2013. See variable definitions below.

Panel B: Correlation coefficients

\begin{tabular}{|c|c|c|c|c|c|c|c|c|c|c|}
\hline Variable & PRICE & RETURN & $L B R$ & $B V$ & $E A R N$ & SIZE & $L V G$ & $G R O$ & $N E R N$ & $C V G$ \\
\hline PRICE & 1.000 & $.253 * * *$ & $.487 * * *$ & $.656 * * *$ & $.704 * * *$ & $.339 * * *$ & 0.008 & $.122 * * *$ & $-.492 * * *$ & $.251 * * *$ \\
\hline RETURN & $.277 * * *$ & 1.000 & $.073 * * *$ & $.103 * * *$ & $.124 * * *$ & 0.013 & $-.056 * * *$ & $.077 * * *$ & $-.227 * * *$ & 0.001 \\
\hline$L B R$ & $.496 * * *$ & $.085 * * *$ & 1.000 & $.746 * * *$ & $.880 * * *$ & $.294 * * *$ & $.378 * * *$ & $-.080 * * *$ & $-.093 * * *$ & $.127 * * *$ \\
\hline$B V$ & $.599 * * *$ & $.141 * * *$ & $.690 * * *$ & 1.000 & $.769 * * *$ & $.312 * * *$ & $-.056 * * *$ & $-.041 * * *$ & $-.216 * * *$ & $.152 * * *$ \\
\hline$E A R N$ & $.711 * * *$ & $.143^{* * *}$ & $.889 * * *$ & $.722 * * *$ & 1.000 & $.358 * * *$ & $.338 * * *$ & $-.049 * * *$ & $-.379 * * *$ & $.170 * * *$ \\
\hline SIZE & $.374 * * *$ & 0.006 & $.247 * * *$ & $.249 * * *$ & $.338 * * *$ & 1.000 & $.249 * * *$ & -0.004 & $-.048 * * *$ & $.509 * * *$ \\
\hline$L V G$ & $.046 * * *$ & $-.090 * * *$ & $.317 * * *$ & $-.126 * * *$ & $.294 * * *$ & $.207 * * *$ & 1.000 & $.023 * *$ & $.081 * * *$ & 0.004 \\
\hline$G R O$ & $.129 * * *$ & $.089 * * *$ & $-.061 * * *$ & $-.044 * * *$ & -0.004 & -0.008 & $-.053 * * *$ & 1.000 & $-.127 * * *$ & -0.014 \\
\hline$N E R N$ & $-.399 * * *$ & $-.251 * * *$ & $-.095 * * *$ & $-.197 * * *$ & $-.313 * * *$ & $-.044 * * *$ & $.107 * * *$ & $-.192 * * *$ & 1.000 & $-.067 * * *$ \\
\hline$C V G$ & $.226^{* * * *}$ & $.022 *$ & $.079 * * *$ & $.115^{* * *}$ & $.137 * * *$ & $.529 * * *$ & 0.007 & $.025 * * *$ & $-.052 * * *$ & 1.000 \\
\hline
\end{tabular}

$* * *, * *, *$ significant at the $0.01,0.05$, and 0.10 level or better (two-sided), respectively.

Panel B presents the Pearson (Spearman) correlation coefficients in the top (bottom) triangle, among the test variables.

\section{Empirical Results: OLS Regression Analysis}

\subsection{Value Relevance of VHCD}

Prior research generally finds that IFRS adoption has not enhanced the association between accounting information and bank value. Most of these studies examine only the adoption period, and use a comparative GAAP and IFRS design (Chalmers Clinch, \& Godfrey, 2008, Clarkson, Hanna, Richardson, \& Thompson, 2010) or examine the value relevance of specific items during the adoption year (Goodwin, Ahmed, \& Heaney, 2008). In contrast, the design for Model 1 and Model 2 includes pre- and post-adoption years after taking into consideration the IFRS transition years. A benefit of this approach is that the results can be compared not only in general with those of prior studies, but also with those of studies investigating IFRS benefits for investors in individual countries, to better understand the effects of country-specific factors on IFRS impact. In Model 3, PREDUM is included in the model to account for pre-adoption years only. The results of estimating all models are reported separately for the full sample period (1998-2013) and an attenuated sample that excludes the transition years (year prior to and year of adoption). The attenuated sample eliminates potential disrupting effects of using new accounting standards in preparing accounting information (Chalmers, Godfrey, \& Webster, 2011).

Table 3 reports OLS regression results of estimating Model 1 testing the value relevance of VHCD. Results are 
reported for non-U.S. and U.S. firms, due to the dominance of U.S. firms in the Compustat Bank file. All (eight) models are well fitted to the data with $f$-statistics that are highly significant (at 1 percent or better) and adjusted $R^{2}$ that range from 0.293 to 0.737 . In general, the results lend strong support to the first hypothesis. As shown in Table 3 , for the full sample, the coefficient estimate for $L B R$ is negative (-.380) and statistically significant at the 1 percent level, consistent with the bank value experiencing adjustments to incorporate VHCD information, as investors relate this information to other information available for the firm, industry averages, competitors, and existing regulations to make useful inferences.

Panel C: Country-level statistics

\begin{tabular}{|c|c|c|c|c|c|c|c|c|c|c|c|c|c|c|c|c|c|c|c|c|}
\hline \multirow[b]{2}{*}{ Country } & \multirow{2}{*}{$\begin{array}{l}\text { Legal } \\
\text { system }\end{array}$} & \multirow{2}{*}{$\begin{array}{l}\text { Bank- } \\
\text { years }\end{array}$} & \multirow[b]{2}{*}{$\%$} & \multirow{2}{*}{\begin{tabular}{|l|} 
IfRS Fiscative \\
Applicalime Dade
\end{tabular}} & \multicolumn{16}{|c|}{ Mean reported labor cost as a percent of year-end total assets } \\
\hline & & & & & 1998 & 1999 & 2000 & 2001 & 2002 & 2003 & 2004 & 2005 & 2006 & 2007 & 2008 & 2009 & 2010 & 2011 & 2012 & 2013 \\
\hline Argentina & Civil & 39 & 0.38 & Not required & . & 2.48 & 2,21 & 2.76 & & 1.51 & 1.73 & 2.09 & 2.55 & 2.96 & 3.57 & 3.52 & 4.00 & 4.01 & 4.27 & 4.30 \\
\hline Brasil & Civil & 40 & 0.39 & $\operatorname{Jan} 1,2010$ & 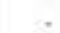 & 3.28 & 2.54 & 3.18 & 2.77 & 2.75 & 2.59 & 2,66 & 2.48 & 1.98 & 1.57 & 1.73 & 1.58 & 1.58 & 1.49 & 1.46 \\
\hline Chile & Civil & 42 & 0.41 & Jan, & 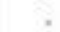 & 1.27 & 1,28 & 1.22 & 1.29 & 1.16 & 1.26 & 1,18 & 1.14 & 1.11 & 1.20 & 1.19 & 1.21 & 1.15 & 1.15 & 1.11 \\
\hline Colombia & Civil & 16 & 0.16 & Jan. 1 & . & 3.68 & 2.67 & 2.45 & 2.51 & 2.41 & 2.36 & 2.00 & 2.00 & 1.81 & 1.74 & 1.85 & 1.90 & 1.69 & 1.67 & 1.27 \\
\hline Denanark & Civil & 6 & 0.06 & Jan. & . & . & & & .53 & .51 & .43 & 32 & .39 & 41 & & & & 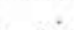 & & \\
\hline France & Civil & 19 & 0,19 & Jan. & . & & & 1.13 & 1,06 & 1.02 & 93 & .75 & .79 & .76 & .76 & .89 & .84 & .82 & .76 & .79 \\
\hline Germany & Civit & 21 & 0.21 & 5 & . & 1,06 & 1.16 & 1.05 & .57 & .76 & .98 & .93 & .78 & .57 & .44 & .75 & .66 & .61 & .67 & 77 \\
\hline Greece & C & 13 & 0.13 & & . & 1.57 & 1.52 & 1.49 & 1,61 & 1.51 & 1.43 & 1,45 & 1.37 & 1.57 & 1.42 & 1.39 & 1.27 & . & + & 1.38 \\
\hline Italy & C & 6 & 0.06 & 5 & 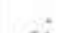 & & 1.12 & 1.30 & 1.40 & 1.40 & 1.33 & 1.08 & & & + & & & & & \\
\hline Japan & ( & 14 & 4 & Nor & 54 & .48 & 43 & & .52 & .49 & 44 & 40 & .46 & 48 & . & .45 & .43 & 42 & 40 & $A 1$ \\
\hline bourg & C & 7 & 7 & I & . & 97 & 97 & 1.03 & .97 & .93 & .93 & .96 & +. & i & . & , & , & . & & \\
\hline Me & c & 2 & 2 &, 2012 & . & & & & & & . & & & & , & , & . & . & 1.03 & 1.05 \\
\hline ands & C & 9 & 9 & n. 1,2005 & $=$ & 1.26 & 1.37 & 1.28 & 1.30 & 1.26 & 1.28 & .85 & .86 & .75 & . & , & & & 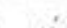 & \\
\hline Par & C & 14 & 0.14 & Nu & 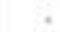 & 19 & 19 & .20 & & .44 & .38 & 41 & .42 & 46 & .46 & 52 & .46 & 46 & 49 & $A 2$ \\
\hline Porth & c & 4 & 4 & 3 & . & 2.17 & 1,97 & 1.17 & 1.27 & & & t. & + & & : & - & & & tat & \\
\hline $\mathrm{s}$. & C & 37 & 6 & 5 & . & 1.14 & .85 & & .88 & .71 & .84 & .99 & .91 & .92 & .62 & .81 & .87 & .74 & .79 & .72 \\
\hline S & Civi & 28 & 0.27 & 05 & . & 1.47 & 1.28 & 1.42 & 1.36 & 1.14 & 83 & .82 & .85 & .29 & .77 & .82 & .82 & .86 & .85 & .93 \\
\hline Sw & C & 4 & 0.04 & & & & & & & & & & & & & & .42 & 53 & 51 & 53 \\
\hline Total civil & & 321 & 3,15 & & .54 & 1.78 & 1.43 & 1.75 & 1.43 & 1.29 & 1.26 & 1,25 & 1.32 & 1.30 & 1.43 & 1.56 & 1.46 & 1.44 & 1.45 & 1.39 \\
\hline Au: & c & 44 & 0.43 & & . & 1.25 & 1.03 & .93 & .92 & .86 & .83 & .85 & .79 & .73 & .65 & .68 & .70 & .66 & .65 & .61 \\
\hline $\mathrm{Be}$ & $a n$ & 1 & 0,13 & Nox & . & 2.35 & 2.25 & 2.29 & 2.15 & 2,14 & 2.23 & 2.14 & 2.35 & 2.31 & 1.75 & 2,12 & & & & \\
\hline ta & m & 9 & 0.93 & 011 & . & 1.35 & 1.46 & 1.40 & 1.41 & 1.41 & 1.41 & 1.31 & 1.23 & 1.17 & .99 & 1.08 & 1,06 & 1.06 & 98 & 97 \\
\hline dit & $\mathrm{m}$ & 2 & 0.28 & 11 & , & .24 & .25 & .30 & .47 & .51 & 57 & .65 & 90 & 91 & 1.03 & .91 & 95 & .95 & .93 & .85 \\
\hline Ireland & $m$ & 2 & 0.20 & lan & . & 1.21 & 1.21 & 1.52 & 1.62 & 1.43 & 96 & .85 & .80 & .77 & .69 & & 60 & .56 & & .62 \\
\hline At & Com & 1 & 0.12 & 1 & . & . & . & 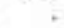 & 1.98 & 1.86 & 1.82 & 1.43 & 1,73 & 1.58 & 1.50 & 1.51 & 1.75 & 1.73 & 1.62 & 1.83 \\
\hline ngapore & $\mathrm{sen}$ & 2 & 0.23 & ne & . & & 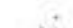 & & .55 & .51 & .49 & .51 & .58 & .60 & .55 & .55 & .58 & .55 & .58 & 56 \\
\hline UK & Comm & 5 & 0.57 & 005 & * & 1.28 & 90 & .89 & 1.03 & .94 & .90 & .89 & .85 & .70 & .62 & .71 & .73 & .69 & .66 & .77 \\
\hline USA & Con & 584 & 3,97 & Nor 1 & & 1,49 & 1.48 & 1.51 & 1.54 & 1.58 & 1.54 & 1.52 & 1.53 & 1.53 & 1.48 & 1.49 & 1.53 & 1.56 & 1.63 & 1.67 \\
\hline \multicolumn{2}{|l|}{ Total common } & 9,878 & 96.85 & & 1,29 & 1.49 & 1.48 & 1.50) & 1.53 & 1.57 & 1.52 & 1.51 & 1.51 & 1.51 & 1.46 & 1.47 & 1.51 & 1.54 & 1.60 & 1.65 \\
\hline Grand total & & 199 & 100 & & & & & & & & & & & & & & & & & \\
\hline
\end{tabular}

Panel C presents the country breakdown of the full sample of 10,199 observations representing 1,498 distinct banks from 27 countries during 1998- 2013. Variables are as defined in Appendix.

These price adjustments could reflect market concerns with competitive consequences from VHCD. Alternatively, these adjustments could reflect concerns with bank operating efficiency based on labor costs incurred. For the attenuated sample, the coefficient estimate is larger (-.373) and still significant at the 1 percent level after eliminating the transitional causes for disrupting the relation between $L B R$ and stock price. Likewise, $L B R$ coefficient estimates for the non-U.S. and U.S. samples are significantly negative (-0.232 significant at the 5 percent level and -0.378 significant at the 1 percent level, respectively). The $L B R$ coefficient estimates in the return models are significantly negative in three of the four return models. As for the control variables, coefficient estimates are mostly significant and in the expected direction. 
Table 3. Testing the value relevance of VHCD

\begin{tabular}{|c|c|c|c|c|c|c|c|c|c|}
\hline \multirow[b]{3}{*}{ Variables } & \multirow{3}{*}{$\begin{array}{l}\text { Expected } \\
\text { sign }\end{array}$} & \multicolumn{8}{|c|}{ Value relevance of VHCD } \\
\hline & & \multicolumn{2}{|c|}{ Full sample } & \multicolumn{2}{|c|}{$\begin{array}{c}\text { Attenuated sample } \\
\text { excluding transition years }\end{array}$} & \multicolumn{2}{|c|}{ Non-U.S. banks } & \multicolumn{2}{|c|}{ U.S. banks } \\
\hline & & Price & Return & Price & Return & Price & Return & Price & Return \\
\hline Constant & & $\begin{array}{r}1.056 \\
(0.000)\end{array}$ & $\begin{array}{r}0.390 \\
(0.003)\end{array}$ & $\begin{array}{r}0.961 \\
(0.000)\end{array}$ & $0.416(0.001)$ & $\begin{array}{r}0.278 \\
(0.832)\end{array}$ & $\begin{array}{r}0.440 \\
(0.702)\end{array}$ & $\begin{array}{r}1.229 \\
(0.000)\end{array}$ & $\begin{array}{r}0.332 \\
(0.006)\end{array}$ \\
\hline$L B R$ & - & $\begin{array}{r}-0.380 \\
(0.000)\end{array}$ & $\begin{array}{r}-0.043 \\
(0.001)\end{array}$ & $\begin{array}{r}-0.373 \\
(0.000)\end{array}$ & $\begin{array}{r}-0.042 \\
(0.001)\end{array}$ & $\begin{array}{r}-0.232 \\
(0.031)\end{array}$ & $\begin{array}{r}-0.114 \\
(0.212)\end{array}$ & $\begin{array}{r}-0.378 \\
(0.000)\end{array}$ & $\begin{array}{r}-0.043 \\
(0.000)\end{array}$ \\
\hline$B V$ & + & $\begin{array}{r}0.526 \\
(0.000)\end{array}$ & $\begin{array}{r}-0.043 \\
(0.000)\end{array}$ & $\begin{array}{r}0.531 \\
(0.000)\end{array}$ & $\begin{array}{r}-0.042 \\
(0.000)\end{array}$ & $\begin{array}{r}0.249 \\
(0.007)\end{array}$ & $\begin{array}{r}0.035 \\
(0.648)\end{array}$ & $\begin{array}{r}0.531 \\
(0.000)\end{array}$ & $\begin{array}{r}-0.045 \\
(0.000)\end{array}$ \\
\hline$E A R N$ & + & $\begin{array}{r}0.617 \\
(0.000)\end{array}$ & $\begin{array}{r}0.110 \\
(0.000)\end{array}$ & $\begin{array}{r}0.609 \\
(0.000)\end{array}$ & $\begin{array}{r}0.108 \\
(0.000)\end{array}$ & $\begin{array}{r}0.639 \\
(0.000)\end{array}$ & $\begin{array}{r}0.187 \\
(0.010)\end{array}$ & $\begin{array}{r}0.617 \\
(0.000)\end{array}$ & $\begin{array}{r}0.106 \\
(0.000)\end{array}$ \\
\hline SIZE & + & $\begin{array}{r}0.091 \\
(0.000)\end{array}$ & $\begin{array}{r}-0.007 \\
(0.022)\end{array}$ & $\begin{array}{r}0.091 \\
(0.000)\end{array}$ & $\begin{array}{r}-0.006 \\
(0.025)\end{array}$ & $\begin{array}{r}0.069 \\
(0.096)\end{array}$ & $\begin{array}{r}-0.111 \\
(0.002)\end{array}$ & $\begin{array}{r}0.091 \\
(0.000)\end{array}$ & $\begin{array}{r}-0.005 \\
(0.053)\end{array}$ \\
\hline$L V G$ & - & $\begin{array}{r}-1.022 \\
(0.000)\end{array}$ & $\begin{array}{r}-0.377 \\
(0.003)\end{array}$ & $\begin{array}{l}-1.039 \\
(0.000)\end{array}$ & $\begin{array}{r}-0.384 \\
(0.002)\end{array}$ & $\begin{array}{r}0.796 \\
(0.545)\end{array}$ & $\begin{array}{r}0.792 \\
(0.496)\end{array}$ & $\begin{array}{r}-1.104 \\
(0.000)\end{array}$ & $\begin{array}{r}-0.334 \\
(0.006)\end{array}$ \\
\hline GRO & + & $\begin{array}{r}0.17 \\
(0.000)\end{array}$ & $\begin{array}{r}0.149 \\
(0.000)\end{array}$ & $\begin{array}{r}0.171 \\
(0.896)\end{array}$ & $\begin{array}{r}0.144 \\
(0.000)\end{array}$ & $\begin{array}{r}0.080 \\
(0.319)\end{array}$ & $\begin{array}{r}0.128 \\
(0.063)\end{array}$ & $\begin{array}{r}0.186 \\
(0.000)\end{array}$ & $\begin{array}{r}0.132 \\
(0.000)\end{array}$ \\
\hline$N E R N$ & - & $\begin{array}{r}0.017 \\
(0.406)\end{array}$ & $\begin{array}{r}-0.022 \\
(0.194)\end{array}$ & $\begin{array}{r}-0.015 \\
(0.000)\end{array}$ & $\begin{array}{r}-0.023 \\
(0.171)\end{array}$ & $\begin{array}{r}0.365 \\
(0.005)\end{array}$ & $\begin{array}{r}0.275 \\
(0.011)\end{array}$ & $\begin{array}{r}0.007 \\
(0.751)\end{array}$ & $\begin{array}{r}-0.036 \\
(0.030)\end{array}$ \\
\hline$C V G$ & + & $\begin{array}{r}0.001 \\
(0.003)\end{array}$ & $\begin{array}{r}0.001 \\
(0.247)\end{array}$ & $\begin{array}{r}0.001 \\
(0.029)\end{array}$ & $\begin{array}{r}0.001 \\
(0.279)\end{array}$ & $\begin{array}{r}0.001 \\
(0.009)\end{array}$ & $\begin{array}{r}0.000 \\
(0.584)\end{array}$ & $\begin{array}{r}0.001 \\
(0.076)\end{array}$ & $\begin{array}{r}0.001 \\
(0.281)\end{array}$ \\
\hline Fixed Effects & & Yes & Yes & Yes & Yes & Yes & Yes & Yes & Yes \\
\hline Bank-years & & 10,199 & 9,948 & 10,076 & 9,829 & 615 & 600 & 9,584 & 9,344 \\
\hline Adj. $R^{2}$ & & .737 & .293 & .735 & .298 & .732 & .350 & .735 & .314 \\
\hline F-Value & & $583.16^{* * *}$ & $85.30 * * *$ & $582.23 * * *$ & $87.77 * * *$ & $35.94 * * *$ & $7.71 * * *$ & $159.27 * * *$ & $187.42 * * *$ \\
\hline
\end{tabular}

***, **,* significant at the $0.01,0.05$, and 0.10 level or better (two-sided), respectively. Table 3 shows the coefficient estimates (p-values) of Model 1 testing value relevance of VHCD (proxied by LBR) using OLS regressions for the full, attenuated, Non-U.S., and U.S. samples during the period 1998-2013. Variables are as defined in Appendix A.

\subsection{IFRS Adoption and the Value Relevance of VHCD}

Table 4 reports results of estimating Model 2, which tests the effects of IFRS adoption on the value relevance of $L B R$. Model statistics indicate that the Model 2 is well fitted to the data with $f$-statistics that are highly significant at the 1 percent level or better. As mentioned earlier, results would support the hypothesized relations in $\mathrm{H} 2$ if the coefficient estimate $\left(\beta_{3}\right)$ for the interaction term $L B R^{*} I F R S$ is insignificant but the coefficient for $L B R\left(\beta_{l}\right)$ maintains its negative and significant sign. Evidence from the price model provides strong support for the second hypothesis that IFRS adoption reduces the value relevance of VHCD. Furthermore, consistent with $\mathrm{H} 2$, the coefficient estimate $\beta_{3}$ in the price and return specifications is insignificant, while $\beta_{1}$ remains significantly negative. Overall, these results provide support to the claim that IFRS adoption reduces the value relevance of VHCD due to the abundance of alternative information provided under the more comprehensive IFRS framework that helps in the prediction of future cash flows. The insignificant $\beta_{3}$ coefficient is potentially indicative of markets in the adopting countries being optimistic about the more accurate assessments of future cash flows promised by the high quality IFRS model. The positive $\beta_{3}$ coefficients in the attenuated sample are potentially a result of the market reassessing the importance of $L B R$ disclosures taking place prior to the mandatory adoption in view of the wider, more comparable disclosure requirements imposed by the IFRS.

Finally, the coefficient estimate for IFRS in the price and return models for the full sample is positive and highly significant, indicating that IFRS positively affects prices upon its mandatory adoption. One reason for this conclusion is that, prior to IFRS adoption, individual nations used local standards that are more aligned with the cultural and economic infrastructure in these nations, but IFRS may be seen as a means of integrating these nations' economies in the global economy and facilitating the flow of international investment funds into local markets (Becht and Roell, 1999; Ding et al., 2007). 
Table 4. Testing the effects of IFRS adoption on value relevance of VHCD

\begin{tabular}{|c|c|c|c|c|c|}
\hline \multirow[b]{3}{*}{ Variables } & \multirow{3}{*}{$\begin{array}{l}\text { Expected } \\
\text { sign }\end{array}$} & \multicolumn{4}{|c|}{ Effects of IFRS adoption on value relevance of VHCD } \\
\hline & & \multicolumn{2}{|c|}{ Full sample } & \multicolumn{2}{|c|}{$\begin{array}{c}\text { Attenuated sample } \\
\text { excluding transition years }\end{array}$} \\
\hline & & Price & Return & Price & Return \\
\hline Constant & & $1.198(0.000)$ & $0.343(0.005)$ & $1.192(0.000)$ & $0.347(0.005)$ \\
\hline$L B R$ & - & $-0.377(0.000)$ & $-0.045(0.000)$ & $-0.372(0.000)$ & $-0.044(0.000)$ \\
\hline IFRS & + & $0.169(0.002)$ & $-0.113(0.010)$ & $0.032(0.625)$ & $-0.097(0.062)$ \\
\hline$L B R * I F R S$ & Ins. & $-0.046(0.157)$ & $0.028(0.296)$ & $0.013(0.748)$ & $0.000(0.994)$ \\
\hline$B V$ & + & $0.525(0.000)$ & $-0.042(0.000)$ & $0.531(0.000)$ & $-0.041(0.000)$ \\
\hline$E A R N$ & + & $0.615(0.000)$ & $0.111(0.000)$ & $0.609(0.000)$ & $0.108(0.000)$ \\
\hline SIZE & + & $0.090(0.000)$ & $-0.006(0.031)$ & $0.091(0.000)$ & $-0.006(0.033)$ \\
\hline$L V G$ & - & $-1.042(0.000)$ & $-0.363(0.004)$ & $-1.047(0.000)$ & $-0.367(0.003)$ \\
\hline GRO & + & $0.173(0.000)$ & $0.148(0.000)$ & $0.171(0.000)$ & $0.143(0.000)$ \\
\hline$N E R N$ & - & $0.016(0.446)$ & $-0.021(0.215)$ & $0.015(0.471)$ & $-0.023(0.177)$ \\
\hline$C V G$ & + & $0.000(0.021)$ & $0.000(0.204)$ & $0.000(0.027)$ & $0.000(0.239)$ \\
\hline Fixed Effects & & Yes & Yes & Yes & Yes \\
\hline Bank-years & & 10199 & 9,947 & 10,075 & 9,828 \\
\hline Adj. $R^{2}$ & & .737 & .294 & .735 & .298 \\
\hline F-Value & & $561.03 * * *$ & $82.17 * * *$ & $558.91 * * *$ & $84.43 * * *$ \\
\hline
\end{tabular}

$* * *, * *, *$ significant at the $0.01,0.05$, and 0.10 level or better (two-sided), respectively. Table 4 shows coefficient estimates (p-values) of Model 2 testing the effect of IFRS mandatory adoption on the value relevance of VHCD using OLS regressions for the sample banks during the period 1998-2013. IFRS is a dummy variable coded as 1 for fiscal years starting on or after January 1, 2005, and 0 otherwise; all variables are as defined in Appendix A.

\subsection{Voluntary IFRS Adoption and the Value Relevance of VHCD}

Table 5 reports results of estimating Model 3, which tests the effects of IFRS adoption on the value relevance of $L B R$ for voluntary adopters. Model statistics indicate that the model is well fitted to the data with $f$-statistics that are highly significant at the 1 percent level or better. The interaction term $L B R^{*} V O L^{*} P R E D U M$ represents voluntary IFRS adopters reporting labor costs before the mandatory adoption year, where PREDUM is coded 1 for years before the year of official mandatory adoption in each represented country and 0 otherwise. Operationally, results would support the hypothesized relations in $\mathrm{H} 3$ if the coefficient estimate $\left(\gamma_{7}\right)$ for the interaction term $L B R^{*} V O L^{*} P R E D U M$ is negative and significant. When PREDUM $=1$, then Model 3 is expressed as follows:

$$
\begin{gathered}
(\text { Stock })_{i t}=\left(\gamma_{0}+\gamma_{3}\right)+\left(\gamma_{1}+\gamma_{6}\right) L B R_{i t}+\left(\gamma_{2}+\gamma_{5}\right) V O L_{i t}+\left(\gamma_{4}+\gamma_{7}\right) L B R_{i t} * V O L_{i t}+\gamma_{8} B V_{i t}+\gamma_{9} E A R N_{i t}+\gamma_{10} S I Z E_{i t}+ \\
\gamma_{11} L V G_{i t}+\gamma_{12} G R O_{i t}+\gamma_{13} N E R N_{i t}+\gamma_{14} C V G_{i t}+Y_{D}+C_{D}+\delta_{i t} \ldots \ldots \ldots
\end{gathered}
$$

When PREDUM $=0$, then the term PREDUM*VOL*LBR $=0$, and Model 3 is expressed as follows:

$$
\begin{gathered}
(\text { Stock })_{i t}=\gamma_{0}+\gamma_{1} L B R_{i t}+\gamma_{2} V O L_{i t}+\gamma_{4} L B R_{i t} * V O L_{i t}+\gamma_{8} B V_{i t}+\gamma_{9} E A R N_{i t}+\gamma_{10} S I Z E_{i t}+\gamma_{11} L V G_{i t}+\gamma_{12} G R O_{i t}+ \\
\gamma_{13} N E R N_{i t}+\gamma_{14} C V G_{i t}+Y_{D}+C_{D}+\delta_{i t} \ldots \ldots \ldots
\end{gathered}
$$

Results reported in Table 5 strongly support $\mathrm{H} 3$ across all (four) models, consistent with the conclusion that the value relevance of VHCD reported by voluntary IFRS adopting banks decreases after IFRS mandatory adoption. That is, voluntary IFRS lose their informational advantage after IFRS becomes mandatory. The coefficient estimate $\left(\gamma_{7}\right)$ for the interaction term in question $L B R^{*} V O L^{*} P R E D U M$ in all four model variations is negative and highly significant. As originally hypothesized, $L B R$ is significantly negative in the price, but not return, models. The dummy variable $V O L$ is insignificant in all models, suggesting that voluntary adopters are not viewed as providing more useful information than before IFRS mandatory adoption. The dummy variable PREDUM is significantly positive in three of the four models. One possible interpretation is that market participants may find their pre-IFRS local accounting standards to better reflect the effects of underlying economic events (and hence these standards are more value relevant), but less informative than IFRS in reflecting change in accounting numbers. This view is consistent with arguments provided by prior research (e.g., Ding et al., 2007). As for the control variables, SIZE and NERN remain the only two variables that are significant and in the expected direction for possible reasons outlined in the Model 1 discussion. 
Table 5. Testing the effects of voluntary adoption of IFRS on the value relevance of VHCD

\begin{tabular}{|c|c|c|c|c|c|}
\hline \multirow[b]{3}{*}{ Variables } & \multirow{3}{*}{$\begin{array}{l}\text { Expected } \\
\text { sign }\end{array}$} & \multicolumn{4}{|c|}{ Effects of voluntary IFRS adoption } \\
\hline & & \multicolumn{2}{|c|}{ Full Sample } & \multicolumn{2}{|c|}{$\begin{array}{c}\text { Attenuated sample } \\
\text { excluding transition years }\end{array}$} \\
\hline & & Price & Return & Price & Return \\
\hline Constant & & $0.258(0.851)$ & $0.227(0.850)$ & $-0.190(0.905)$ & $1.115(0.437)$ \\
\hline$L B R$ & - & $-0.299(0.007)$ & $-0.096(0.328)$ & $-0.209(0.095)$ & $-0.027(0.813)$ \\
\hline$V O L$ & + & $0.005(0.891)$ & $0.003(0.442)$ & $0.009(0.564)$ & $0.004(0.392)$ \\
\hline PREDUM & $?$ & $0.132(0.062)$ & $0.113(0.010)$ & $0.274(0.007)$ & $0.037(0.673)$ \\
\hline$L B R * V O L$ & $?$ & $0.222(0.052)$ & $0.035(0.098)$ & $0.282(0.011)$ & $0.030(0.067)$ \\
\hline$V O L * P R E D U M$ & $?$ & $0.033(0.918)$ & $0.077(0.441)$ & $0.028(0.412)$ & $0.073(0.276)$ \\
\hline$L B R^{*} P R E D U M$ & $?$ & $-0.087(0.062)$ & $-0.028(0.297)$ & $-0.065(0.033)$ & $-0.026(0.301)$ \\
\hline$L B R^{*} V O L^{*} P R E D U M$ & - & $-1.973(0.001)$ & $-1.631(0.000)$ & $-1.868(0.000)$ & $-1.594(0.000)$ \\
\hline$B V$ & + & $0.246(0.008)$ & $0.048(0.548)$ & $0.321(0.003)$ & $0.032(0.732)$ \\
\hline$E A R N$ & + & $0.683(0.000)$ & $0.172(0.025)$ & $0.564(0.000)$ & $0.125(0.145)$ \\
\hline SIZE & + & $0.030(0.451)$ & $-0.114(0.001)$ & $0.050(0.302)$ & $-0.126(0.004)$ \\
\hline$L V G$ & - & $1.248(0.356)$ & $0.987(0.401)$ & $1.063(0.504)$ & $0.089(0.950)$ \\
\hline$G R O$ & + & $0.019(0.821)$ & $0.035(0.625)$ & $0.012(0.896)$ & $-0.014(0.865)$ \\
\hline$N E R N$ & - & $-0.331(0.009)$ & $-0.336(0.002)$ & $-0.300(0.028)$ & $-0.341(0.005)$ \\
\hline$C V G$ & + & $0.001(0.021)$ & $0.000(0.650)$ & $0.001(0.055)$ & $0.000(0.756)$ \\
\hline Fixed Effects & & Yes & Yes & Yes & Yes \\
\hline Bank-years & & 572 & 558 & 449 & 419 \\
\hline Adj. $\mathrm{R}^{2}$ & & .738 & .365 & .737 & .372 \\
\hline F-Value & & $35.213 * * *$ & $7.97 * * *$ & $28.87 * * *$ & $6.77 * * *$ \\
\hline
\end{tabular}

***, **, * significant at the $0.01,0.05$, and 0.10 level or better (two-sided), respectively. Table 5 shows the coefficient estimates (p-values) of Model 3 testing the effects of IFRS adoption on the value relevance of labor costs across sample banks for voluntary adopters. All variables are as defined in Appendix A.

\section{Supplemental Analysis}

Legal systems prevailing in the countries represented in the full sample are diverse. Those can be broadly classified into common and civil law countries. The differences in the legal infrastructure due to this classification have far-reaching implications for economic choices of these nations. The analysis conducted in this study cannot be complete without examining the same research questions separately for common and civil law countries. Common law countries typically involve more dependence on equity financing, more fragmented ownership base, and more active stock markets compared to civil law countries (La Porta et al., 1997; Ball et al., 2000). In the sample, bank-year observations from common law countries equal 9,878 bank-years ( 96.85 percent of total observations), while those from civil law countries equal 321 bank-years (3.15 percent of total observations). Accordingly, the analysis is rerun for Models 1-3 after partitioning the sample based on the dominant legal system. Results are shown in Tables 6, 7 and 8.

Table 6 shows the results of running Model 1 (testing H1) across the two legal system-based sample partitions. All models are well-specified and have highly significant $f$-statistics. Results provide more detailed insights on the role of legal systems in the hypothesized relations. VHCD is value relevant in common law countries in the case of non-IFRS adopting banks only and in civil law countries in the case of IFRS-adopting banks only. These results are in line with the main analysis. One explanation for the significant $L B R$ coefficient in non-IFRS, but not IFRS, banks is that investors in banks adopting IFRS in common law countries may find that the availability of comprehensive financial information required by IFRS mitigates the lack of abundance of human capital information in predicting the bank's future stream of cash flows. This may not be the case in non-IFRS banks, where VHCD information has the benefit of shedding light on one of the drivers of firm performance that may not be available under local (non-IFRS) standards.

Table 7 shows the results of estimating Model 2 (testing H2) across the legal system partitions. All four models are well specified, with highly significant $f$-statistics. However, results are different from those obtained from running the main analysis, reported in Table 4. The coefficient estimate of the interaction term of interest ( $\left.L B R^{*} I F R S\right)$ is insignificant across three of the four models, consistent with legal systems largely not being an intervening factor in the question of whether IFRS mandatory adoption affects the value relevance of VHCD. However, the coefficient estimate for the 
interaction term in the price model is positive and significant, which contradicts results of the main analysis. This result cannot be viewed in isolation from the negative and significant IFRS coefficient. The positive and significant interaction term in common law countries may indicate that VHCD have added value after IFRS adoption in these countries, but that IFRS adoption is seen by market participants as an added burden that requires time and financial investment. The negative and significant coefficient estimate for IFRS for the civil law countries is potentially indicative of market participants in these countries viewing the adoption of IFRS negatively. Recall that in civil law countries, debt financing is predominant and ownership is typically highly concentrated (Becht \& Roell, 1999). The negative coefficient is therefore not surprising in this context.

Table 8 shows the results of estimating Model 3 (testing H3) across the common and civil law sample partitions. Similar to earlier analyses, all four models are well specified, with highly significant $f$-statistics. The results add a deeper perspective to that offered by the main analysis reported in Table 5. The interaction term of interest $\left(L B R^{*} V O L^{*} P R E D U M\right)$ is highly significant for the price models in the common and civil law countries; however, the sign of the coefficient is negative (as expected) for the civil law countries and positive for common law countries. The reason is potentially because civil law countries are dependent on debt financing and the value placed by market participants on accounting information decreases after the mandatory IFRS adoption, which is a comprehensive and high quality accounting standards. On the other hand, VHCD in common law countries possesses value relevance for the voluntary IFRS adopting banks prior to mandatory IFRS adoption and that this value relevance increases after the mandatory adoption. In the returns model specification, the interaction term is insignificant, consistent with changes in VHCD provided by the banks not being incorporated into changes in equity returns both before and after the mandatory IFRS adoption. Based on the results from the main analysis and the analysis in this section, it is concluded that $\mathrm{H} 3$ is supported but only for civil law countries but not for common law countries.

Table 6. Testing value relevance of VHCD in different legal systems

\begin{tabular}{|c|c|c|c|c|c|c|c|c|c|}
\hline \multirow[b]{4}{*}{ Variables } & \multirow{4}{*}{$\begin{array}{l}\text { Expected } \\
\text { sign }\end{array}$} & \multicolumn{8}{|c|}{ Value relevance of VHCD in different legal systems } \\
\hline & & \multicolumn{4}{|c|}{ Common law countries } & \multicolumn{4}{|c|}{ Civil law countries } \\
\hline & & \multicolumn{2}{|c|}{ IFRS banks } & \multicolumn{2}{|c|}{ Non-IFRS banks } & \multicolumn{2}{|c|}{ IFRS banks } & \multicolumn{2}{|c|}{ Non-IFRS banks } \\
\hline & & Price & Return & Price & Return & Price & Return & Price & Return \\
\hline Constant & + & $\begin{array}{l}10.026 \\
(0.005)\end{array}$ & $\begin{array}{r}0.417 \\
(0.865)\end{array}$ & $\begin{array}{r}1.009 \\
(0.000)\end{array}$ & $\begin{array}{r}0.761 \\
(0.000)\end{array}$ & $\begin{array}{c}-1.038 \\
(0.946)\end{array}$ & $\begin{array}{r}0.220 \\
(0.870)\end{array}$ & $\begin{array}{r}0.094 \\
(0.929)\end{array}$ & $\begin{array}{r}6.821 \\
(0.798)\end{array}$ \\
\hline$L B R$ & - & $\begin{array}{l}-0.144 \\
(0.455)\end{array}$ & $\begin{array}{r}-0.028 \\
(0.838)\end{array}$ & $\begin{array}{r}-0.380 \\
(0.000)\end{array}$ & $\begin{array}{l}-0.044 \\
(0.000)\end{array}$ & $\begin{array}{r}-2.587 \\
(0.070)\end{array}$ & $\begin{array}{r}-0.123 \\
(0.401)\end{array}$ & $\begin{array}{r}0.079 \\
(0.506)\end{array}$ & $\begin{array}{r}-1.099 \\
(0.601)\end{array}$ \\
\hline$B V$ & + & $\begin{array}{r}-0.290 \\
(0.082)\end{array}$ & $\begin{array}{r}0.000 \\
(0.997)\end{array}$ & $\begin{array}{r}0.531 \\
(0.000)\end{array}$ & $\begin{array}{l}-0.045 \\
(0.000)\end{array}$ & $\begin{array}{r}1.426 \\
(0.221)\end{array}$ & $\begin{array}{r}0.071 \\
(0.524)\end{array}$ & $\begin{array}{r}0.283 \\
(0.002)\end{array}$ & $\begin{array}{r}1.915 \\
(0.332)\end{array}$ \\
\hline EARN & + & $\begin{array}{r}0.966 \\
(0.000)\end{array}$ & $\begin{array}{r}0.103 \\
(0.376)\end{array}$ & $\begin{array}{r}0.620 \\
(0.000)\end{array}$ & $\begin{array}{r}0.107 \\
(0.000)\end{array}$ & $\begin{array}{r}1.868 \\
(0.008)\end{array}$ & $\begin{array}{r}0.184 \\
(0.082)\end{array}$ & $\begin{array}{r}0.356 \\
(0.000)\end{array}$ & $\begin{array}{r}1.090 \\
(0.208)\end{array}$ \\
\hline SIZE & + & $\begin{array}{r}-0.068 \\
(0.701)\end{array}$ & $\begin{array}{r}0.208 \\
(0.094)\end{array}$ & $\begin{array}{r}0.188 \\
(0.000)\end{array}$ & $\begin{array}{r}0.132 \\
(0.000)\end{array}$ & $\begin{array}{r}0.066 \\
(0.843)\end{array}$ & $\begin{array}{r}0.011 \\
(0.903)\end{array}$ & $\begin{array}{r}0.078 \\
(0.292)\end{array}$ & $\begin{array}{r}-0.158 \\
(0.787)\end{array}$ \\
\hline$L V G$ & - & $\begin{array}{r}-0.089 \\
(0.154)\end{array}$ & $\begin{array}{r}-0.046 \\
(0.302)\end{array}$ & $\begin{array}{r}0.091 \\
(0.000)\end{array}$ & $\begin{array}{l}-0.006 \\
(0.051)\end{array}$ & $\begin{array}{r}1.700 \\
(0.005)\end{array}$ & $\begin{array}{r}-0.183 \\
(0.003)\end{array}$ & $\begin{array}{r}0.255 \\
(0.000)\end{array}$ & $\begin{array}{r}-0.937 \\
(0.199)\end{array}$ \\
\hline GRO & + & $\begin{array}{r}0.002 \\
(0.013)\end{array}$ & $\begin{array}{r}0.000 \\
(0.929)\end{array}$ & $\begin{array}{r}0.000 \\
(0.076)\end{array}$ & $\begin{array}{r}0.000 \\
(0.279)\end{array}$ & $\begin{array}{r}-0.021 \\
(0.077)\end{array}$ & $\begin{array}{r}0.000 \\
(0.807)\end{array}$ & $\begin{array}{r}0.000 \\
(0.839)\end{array}$ & $\begin{array}{r}-0.010 \\
(0.556)\end{array}$ \\
\hline$N E R N$ & - & $\begin{array}{r}-6.712 \\
(0.051)\end{array}$ & $\begin{array}{r}0.129 \\
(0.957)\end{array}$ & $\begin{array}{r}-1.102 \\
(0.000)\end{array}$ & $\begin{array}{l}-0.338 \\
(0.006)\end{array}$ & $\begin{array}{r}-15.925 \\
(0.309)\end{array}$ & $\begin{array}{r}2.117 \\
(0.176)\end{array}$ & $\begin{array}{l}-1.144 \\
(0.355)\end{array}$ & $\begin{array}{r}-4.595 \\
(0.859)\end{array}$ \\
\hline$C V G$ & + & $\begin{array}{r}0.313 \\
(0.160)\end{array}$ & $\begin{array}{r}0.299 \\
(0.057)\end{array}$ & $\begin{array}{r}0.009 \\
(0.684)\end{array}$ & $\begin{array}{l}-0.035 \\
(0.035)\end{array}$ & $\begin{array}{r}3.790 \\
(0.014)\end{array}$ & $\begin{array}{r}0.226 \\
(0.167)\end{array}$ & $\begin{array}{r}0.309 \\
(0.024)\end{array}$ & $\begin{array}{r}1.080 \\
(0.573)\end{array}$ \\
\hline Fixed Effe & & Yes & Yes & Yes & Yes & Yes & Yes & Yes & Yes \\
\hline Bank-year & & 281 & 277 & 9597 & 9,360 & 29 & 281 & 290 & 213 \\
\hline Adj. $R^{2}$ & & .622 & .272 & .735 & .314 & .949 & .444 & .836 & .422 \\
\hline F-Value & & $17.47 * * *$ & $4.69^{* * *}$ & $1,111.64 * * *$ & $179.76^{* * *}$ & $23.57 * * *$ & $7.042^{* * *}$ & $41.06^{* * * *}$ & $5.075^{* * *}$ \\
\hline
\end{tabular}

$* * *, * *, *$ significant at the $0.01,0.05$, and 0.10 level or better (two-sided), respectively. Table 6 shows the coefficient estimates ( $p$-values) of Model 1 testing value relevance of labor costs $(L B R)$ using OLS regressions after breaking the sample based on IFRS adoption and legal system. All variables are as defined in Appendix A. 
Table 7. Testing the effects of IFRS adoption on value relevance of VHCD in different legal systems

\begin{tabular}{|c|c|c|c|c|c|}
\hline \multirow[b]{3}{*}{ Variables } & \multirow{3}{*}{$\begin{array}{l}\text { Expected } \\
\text { sign }\end{array}$} & \multicolumn{4}{|c|}{ Effects of IFRS adoption on value relevance of VHCD } \\
\hline & & \multicolumn{2}{|c|}{ Common law countries } & \multicolumn{2}{|c|}{ Civil law countries } \\
\hline & & Price & Return & Price & Return \\
\hline Constant & + & $11.393(0.002)$ & $-0.154(0.953)$ & $-0.120(0.913)$ & $-0.223(0.870)$ \\
\hline$L B R$ & - & $-0.156(0.414)$ & $-0.051(0.716)$ & $0.022(0.856)$ & $-0.115(0.454)$ \\
\hline IFRS & + & $-0.607(0.000)$ & $-0.088(0.442)$ & $-0.189(0.057)$ & $0.037(0.761)$ \\
\hline$L B R * I F R S$ & Ins. & $0.211(0.005)$ & $-0.002(0.976)$ & $0.063(0.199)$ & $-0.021(0.728)$ \\
\hline$B V$ & + & $-0.428(0.017)$ & $0.017(0.894)$ & $0.321(0.001)$ & $0.069(0.556)$ \\
\hline$E A R N$ & + & $0.995(0.000)$ & $0.110(0.347)$ & $0.363(0.000)$ & $0.184(0.085)$ \\
\hline$S I Z E$ & + & $-0.045(0.474)$ & $-0.043(0.343)$ & $0.273(0.000)$ & $-0.186(0.003)$ \\
\hline$L V G$ & - & $-8.044(0.024)$ & $0.633(0.805)$ & $-1.179(0.349)$ & $2.216(0.168)$ \\
\hline$G R O$ & + & $-0.063(0.714)$ & $0.216(0.085)$ & $0.068(0.355)$ & $0.011(0.902)$ \\
\hline$N E R N$ & - & $0.413(0.062)$ & $0.296(0.064)$ & $0.336(0.015)$ & $0.221(0.181)$ \\
\hline$C V G$ & + & $0.002(0.019)$ & $0.000(0.879)$ & $0.000(0.967)$ & $0.000(0.831)$ \\
\hline Fixed Effects & & Yes & Yes & Yes & Yes \\
\hline Bank-years & & 281 & 277 & 291 & 281 \\
\hline Adj. $\mathrm{R}^{2}$ & & .640 & .270 & .837 & .440 \\
\hline F-Value & & $17.61 * * *$ & $4.395 * * *$ & $39.31 * * *$ & $6.633 * * *$ \\
\hline
\end{tabular}

\begin{tabular}{|c|c|c|c|c|c|}
\hline \multirow[b]{3}{*}{ Variables } & \multirow{3}{*}{$\begin{array}{c}\text { Expected } \\
\text { sign }\end{array}$} & \multicolumn{4}{|c|}{ Effects of voluntary IFRS adoption by legal system } \\
\hline & & \multicolumn{2}{|c|}{ Common law countries } & \multicolumn{2}{|c|}{ Civil law countries } \\
\hline & & Price & Return & Price & Return \\
\hline Constant & & $8.438(0.018)$ & $1.435(0.012)$ & $-0.706(0.518)$ & $-0.569(0.668)$ \\
\hline$L B R$ & - & $-0.214(0.267)$ & $-0.144(0.347)$ & $-0.052(0.665)$ & $-0.229(0.123)$ \\
\hline$V O L$ & + & $0.309(0.011)$ & $0.382(0.211)$ & $-0.085(0.775)$ & $0.020(0.823)$ \\
\hline PREDUM & $?$ & $-0.236(0.156)$ & $0.309(0.011)$ & $0.122(0.101)$ & $-2.037(0.000)$ \\
\hline$L B R * V O L$ & $?$ & $-0.081(0.012)$ & $-0.120(0.231)$ & $-0.071(0.010)$ & $-0.087(0.049)$ \\
\hline$V O L * P R E D U M$ & $?$ & $0.028(0.300)$ & $0.029(0.381)$ & $-0.218(0.506)$ & $0.067(0.189)$ \\
\hline$L B R * P R E D U M$ & $?$ & $0.079(0.065)$ & $-0.012(0.722)$ & $-0.062(0.243)$ & $0.031(0.605)$ \\
\hline$L B R^{*} V O L * P R E D U M$ & - & $0.983(0.000)$ & $-0.236(0.156)$ & $-1.669(0.000)$ & $0.104(0.357)$ \\
\hline$B V$ & + & $-0.040(0.820)$ & $0.983(0.000)$ & $0.354(0.000)$ & $0.259(0.012)$ \\
\hline$E A R N$ & + & $-0.083(0.182)$ & $-0.040(0.820)$ & $0.428(0.000)$ & $-0.041(0.639)$ \\
\hline$S I Z E$ & + & $-5.164(0.134)$ & $0.002(0.008)$ & $0.245(0.000)$ & $-0.001(0.528)$ \\
\hline$L V G$ & - & $-0.535(0.005)$ & $0.299(0.174)$ & $-0.411(0.741)$ & $0.271(0.088)$ \\
\hline$G R O$ & + & $0.002(0.008)$ & $-0.083(0.182)$ & $0.017(0.816)$ & $-0.202(0.001)$ \\
\hline$N E R N$ & - & $8.438(0.018)$ & $-0.535(0.005)$ & $0.372(0.005)$ & $0.101(0.457)$ \\
\hline$C V G$ & + & $0.299(0.174)$ & $-5.164(0.134)$ & $0.000(0.829)$ & $2.387(0.114)$ \\
\hline Fixed Effects & & Yes & Yes & Yes & Yes \\
\hline Bank-years & & 9,878 & 9,637 & 321 & 311 \\
\hline Adj. $R^{2}$ & & .736 & .306 & .850 & .486 \\
\hline F-Value & & $837.00 * * *$ & $130.02 * * *$ & $179.52 * * *$ & $7.79 * * *$ \\
\hline
\end{tabular}




\section{Conclusion and Recommendations}

\subsection{Discussion}

This study examines the value relevance of VHCD in the banking industry. To conduct this investigation, a sample of 10,199 cross-country bank-year observations is generated and VHCD is proxied for by labor costs. Value relevance is measured using price and return specifications. Measuring value relevance using returns serves to determine whether price changes correspond to changes in the variable of interest (labor costs). The results provide strong evidence suggesting that market participants consider VHCD to be value relevant and incorporate changes in labor cost information into their pricing decisions, regardless of the legal system a bank is subject to (common or civil law countries). Market participants, however, are found to relate VHCD negatively to prices and returns. Potentially, these participants are concerned with competitive consequences of such disclosures or operating efficiency issues.

Results also provide support for the claim that IFRS adoption reduces the value relevance of VHCD due to the abundance of alternative information provided under the more comprehensive IFRS framework that helps in the prediction of future cash flows. It was also found that predominant legal system is largely not an intervening factor in the question of whether IFRS mandatory adoption affects the value relevance of VHCD. Finally, the value relevance of VHCD reported by voluntary IFRS adopting banks is higher before the mandatory adoption year than after that year. After taking legal systems into consideration, market participants find VHCD value relevant after IFRS adoption in common law countries potentially because it reduces uncertainty about an important determinant of the bank's future performance. On the other hand, market participants in civil law countries view VHCD as value relevant but coming at added time and financial investment.

\subsection{Contributions and Suggestions for Future Research}

This study makes a number of contributions to the extant literature. First, within the literature on human capital accounting, this is the first study to present empirical evidence based on a cross-country sample of 27 nations that recently fully adopted IFRS. Most human capital studies focus on individual nations (such as, Lajili and Zeghal (2005) who use a U.S. sample and Samudhram et al. (2014) who use a Malaysian sample) and hence their results may be affected by country-specific regulatory, economic or other factors. Second, within value relevance literature, this is the first empirical study to examine the usefulness of VHCD in an IFRS-based regime, extending prior research covering developed markets. Thirdly, it indicates that voluntary disclosures may be employed to overcome the limitations of IFRS, and disclose intangible assets to shed light on the bank-specific strengths.

The results initiate an argument on whether human capital disclosures should move from the voluntary to the mandatory reporting domain. While value relevance is not specifically considered by accounting regulators (Barth et al., 2001), the results in this paper may be of interest to bank regulators on the issue of requiring banks to disclose detailed labor cost information in separate income statement line item(s). Requiring human capital disclosures may be useful to market participants, especially in markets adopting IFRS, at a time when the U.S. capital markets are gradually converging U.S. GAAP to IFRS. Overall, this paper evaluates the value relevance of VHCD, as well as assessing the role of IFRS and voluntary disclosure in this relation, which fills a gap in the relevant literature for cross-country studies. To the best of the knowledge, this is the first study on the value relevance of VHCD in a cross-country setting. It remains for future research to be conducted in individual countries to see how these results hold, and it would also be useful to compare the valuation implication of other accounting items after implementation of IFRS. In addition, several studies reveal that the purpose of providing VHCD is due to seeking legitimacy or managing relations with powerful resource providers (Abeysekera, 2008). Therefore, future research examining whether mandatorily requiring human capital disclosures as income statement line item or footnote disclosure helps banks earn legitimacy and helps market participants assess the appropriateness of bank human capital practices.

\subsection{Study Limitations}

The study results are subject to some limitations. Firstly, the choice of variables requires careful interpretation of the results. In particular, operationalizing VHCD as labor costs focuses on the quantitative aspects of human capital disclosures and ignores the qualitative aspects of these disclosures, which may be argued to be potentially more important than the quantitative aspects. The choice of labor costs to represent VHCD is motivated by the absence of IFRS and U.S. GAAP requirements for detailed labor-related disclosures. The voluntary nature of human capital disclosures results in large variations among firms in terms of the type, frequency and content they choose to disclose. This variation increases the attractiveness of using labor costs as an audited, objective measure of financial labor costs. Furthermore, labor costs are an example of input measures, which ignore the impact of labor practices adopted by a bank. Output measures, such as labor productivity, might better reflect the impact of corporate labor practices, but this study 
focuses on the corporate decision to disclose human capital information and the market reaction to that decision. Secondly, the choice of sample banks is potentially affected by a self-selection bias, because, by construction, the study uses banks that report labor costs and excludes those that do not.

\subsection{Implications to the Egyptian Accounting Profession, Banking Sector and Capital Markets}

In this section, the results of the paper are applied to an emerging economy, Egypt, which has a well-established banking sector. Egypt is an emerging economy with wide ranging investment opportunities. Local and foreign banks compete openly in the Egyptian financing product, capital and labor markets. The labor practices in many local companies are gradually coming in line to the global practices of foreign entities. Recent reports by international organizations examining disclosure practices of listed Egyptian firms in general suggest that level of disclosure provided by these firms is less than desirable (World Bank, 2002, 2004; UNCTAD, 2008). These reports highlight recent improvements in corporate disclosures, make policy recommendations, and provide investors with a benchmark against which to assess degree of enforcement and compliance with disclosure requirements in Egypt. In recent years there have been a number of major reforms, mostly incorporated in new stock exchange listing rules. However, the implementation and enforcement of these rules are different issues altogether.

The results of this study provide insights to an emerging economy like Egypt on the benefits of offering disclosures on human capital practices. Market participants in the sampled countries find VHCD value relevant, especially in civil law countries like Egypt. There are a number of parallels between the Egyptian and the economic environments in the countries of the sample banks, which facilitate drawing inferences on the Egyptian case. First, the legal environment in Egypt is firmly rooted in civil law traditions. Second, many of the sample countries (e.g., U.S.) actively engage in economic trade with Egypt. Third, many firms operating in Egypt have international ownership. The existence of these parallels mean that significant relations found in a cross-country sample may apply equally well in an Egyptian setting, despite differences in regulatory and economic infrastructures. While the IFRS-based Egyptian Accounting Standards do not mandate disclosures related to human capital, it is expected that Egyptian banks volunteering additional information in their financial statements would benefit by seeing their stock prices traded at a premium, as the results of this study suggest. The mere disclosure of human capital related items is expected to improve the liquidity of the shares of the reporting Egyptian banks because of the reduced uncertainty related to this bank. Further, foreign investors are attracted to banks with intellectual capital potential, which could be observed from VHCD.

In general, well-governed banks provide additional disclosures to its stakeholders. The importance of corporate governance for developing countries, like Egypt, was shown by a study that was performed in 2002 by McKinsey Consulting that surveyed over 200 institutional investors. The results of the survey showed that 80 percent of the respondents were ready to pay a premium for well-governed companies. The study further indicated that this premium amounted to 40 per cent in the case of Egypt. Improving corporate governance in Egypt, therefore, is a means of creating value for the country's enterprises and economy as a whole (UNCTAD, 2008). The recommendation to Egyptian policy makers is to encourage Egyptian banks to provide additional disclosures related to human capital and other relevant issues. For example, the Egyptian stock market could create a measure for good governance, reward well-governed banks publicly, and educate banks on the importance of providing human capital disclosures voluntarily. Market disciplining and prudential regulatory oversight are not possible without transparent financial reports. Through these reports, the Central Bank of Egypt is able to assess whether banks are using their resources effectively and fully at an appropriate level of risk. Human capital disclosures are especially important if the banking sector would like to remain competitive in attracting and retaining qualified personnel. Investors and depositors alike are expected to prefer banks with internal policies that favor fair employment practices. Banks that do not adopt fair practices with respect to their labor may eventually incur additional costs, such as employee litigation, poor services, poor customer services and higher cost of capital. The results of this study shows that investors value human capital disclosures and Egyptian banks should strive for continuous improvement in this regard.

\section{References}

Abdel-khalik, A. R. (2003). Self-sorting, incentive compensation and human-capital assets. European Accounting Review, 12(4), 661-697. http://dx.doi.org/10.1080/09638180310001628428

Abeysekera, I. (2008), Motivations behind human capital disclosure in annual reports, Accounting Forum, 32(1), 16-29. http://dx.doi.org/10.1016/j.accfor.2006.11.006

Aharony, J., Barniv, R. \& Falk, H. (2010). The impact of mandatory IFRS adoption on equity valuation of accounting numbers for security investors in the EU, European Accounting Review, 19(3), 535-578. http://dx.doi.org/10.1080/09638180.2010.506285 
Ahmed, K., \& Falk, H. (2006). The value relevance of management's research and development reporting choice: Evidence from Australia. Journal of Accounting and Public Policy, 25, 231-264. http://dx.doi.org/10.1016/j.jaccpubpol.2006.03.002

An, Y., Davey, H., \& Eggleton, I.R.C. (2011). Towards a comprehensive theoretical framework for voluntary IC disclosure. Journal of Intellectual Capital, 12(4), 571-585. http://dx.doi.org/10.1108/14691931111181733

Armstrong, C. S., Barth, M. E., Jagolinzer, A. D., \& Riedl, E. J. (2010). Market reaction to the adoption of IFRS in Europe. The Accounting Review, 85(1), 31-61. http://dx.doi.org/10.2308/accr.2010.85.1.31

Ashbaugh, H., \& Pincus, M. (2001). Domestic accounting standards, international accounting standards, and the predictability of earnings. Journal of Accounting Research, 39(3): 417-434. http://dx.doi.org/10.1111/1475-679X.00020

Ball, R., Kothari, S., \& Robin, A. (2000). The effect of international institutional factors on properties of accounting earnings. Journal of Accounting and Economics, 29, 1-52. http://dx.doi.org/10.1016/S0165-4101(00)00012-4

Ball, R. (2006). International Financial Reporting Standards (IFRSs): Pros and cons for investors. Accounting \& Business Research, 36(Supplement), 5-27. http://dx.doi.org/10.1080/00014788.2006.9730040

Ballester, M., Livnat, J., \& Sinha, N. (2002). Labor costs and investments in human capital. Journal of Accounting, Auditing and Finance, 17(4), 351-73.

Banghøj J., \& Plenborg T. (2008), Value relevance of voluntary disclosure in the annual report, Accounting \& Finance, 48(2), 159-180. http://dx.doi.org/10.1111/j.1467-629X.2007.00240.x

Barth, M.E., Beaver, W.H., \& Landsman, W.R. (2001). The relevance of the value relevance literature for financial accounting standard setting: Another view. Journal of Accounting \& Economics, 31(1), 77-104. http://dx.doi.org/10.1016/S0165-4101(01)00019-2

Barth, M.E., \& Clinch, G. (2009). Scale effects in capital markets-based. Journal of Business Finance \& Accounting, 36, 253-288. http://dx.doi.org/10.1111/j.1468-5957.2009.02133.x

Barth, M.E., Landsman, W.R. \& Lang, M.H. (2008). International Accounting Standards and accounting quality, Journal of Accounting Research, 46(3), 467-498. http://dx.doi.org/10.1111/j.1475-679X.2008.00287.x

Bartov, E., Goldberg, S., \& Kim, M. (2005). Comparative value relevance among German, U.S., and international accounting standards: A German stock market perspective. Journal of Accounting, Auditing and Finance, 20(2), 95-119.

Basu, S. (1997). The conservatism principle and the asymmetric timeliness of earnings, Journal of Accounting \& Economics, 24(1), 3-37. http://dx.doi.org/10.1016/S0165-4101(97)00014-1

Beaver, W. (2002) Perspectives in recent capital markets research. The Accounting Review, 77(2), 453-474. http://dx.doi.org/10.2308/accr.2002.77.2.453

Becht, M., \& Röell, A. (1999). Blockholdings in Europe: An international comparison. European Economic Review, 43(4), 1049-1056. http://dx.doi.org/10.1016/S0014-2921(98)00113-5

Botosan, C.A. (1997). Disclosure level and the cost of equity capital. The Accounting Review, 72(3), 323-334.

Botosan, C.A., \& Plumlee, M.A. (2002). A re-examination of disclosure level and expected cost of equity capital. Journal of Accounting Research, 40(1), 21-40. http://dx.doi.org/10.1111/1475-679X.00037

Bukh, P. (2003). The relevance of intellectual capital disclosure: a paradox? Accounting, Auditing \& Accountability Journal, 16(1), 49-56. http://dx.doi.org/10.1108/09513570310464273

Chalmers, K., Clinch, G., \& Godfrey, J.M. (2008). Adoption of International Financial Reporting Standards: Impact on the value relevance of intangible assets. Australian Accounting Review, 18, 237-247. http://dx.doi.org/10.1111/j.1835-2561.2008.0028.x

Chalmers, K., Godfrey, J., \& Webster, J. (2011). Does a goodwill impairment regime better reflect the underlying economic attributes of goodwill? Accounting \& Finance, 51, 634-660. http://dx.doi.org/10.1111/j.1467-629X.2010.00364.x

Clarkson, P., Hanna, J.D., Richardson, G.D., \& Thompson, R. (2010). The impact of IFRS adoption on the value relevance of book value and earnings. Working paper, Simon Fraser University. 
Collins, D., Kothari, S.P., Shanken, J. \& Sloan, R. (1994). Lack of timeliness and noise as explanations for the low contemporaneous return-earnings association. Journal of Accounting \& Economics, 18(3), 289-324. http://dx.doi.org/10.1016/0165-4101(94)90024-8

Collins, D., Maydew, E., \& Weiss, I. (1997). Changes in the value-relevance of earnings and book-values in the past forty years. Journal of Accounting \& Economics, 24(1), 39-67. http://dx.doi.org/10.1016/S0165-4101(97)00015-3

Core, J., Guay, W., \& Buskirk, A. (2003). Market valuations in the New Economy: an investigation of what has changed. Journal of Accounting \& Economics, $34(1-3), \quad 43 \quad-\quad 67$. http://dx.doi.org/10.1016/S0165-4101(02)00087-3

Covrig, V.M., DeFond, M.L., \& Hung, M. (2007). Home bias, foreign mutual fund holdings, and the voluntary adoption of international accounting standards. Journal of Accounting Research, 45(1): 41-70. http://dx.doi.org/10.1111/j.1475-679X.2007.00226.x

Daske, H., Hail, L., Leuz, C., \& Verdi, R. (2011). Adopting a Label: Heterogeneity in the Economic Consequences of IFRS Adoption. Working paper, Goethe University of Frankfurt, University of Pennsylvania, The University of Chicago, and Massachusetts Institute of Technology.

Devalle, A., Onali, E., \& Magarini, R. (2010). Assessing the value relevance of accounting data after the introduction of IFRS in Europe. Journal of International Financial Management \& Accounting, 21, 85-119. http://dx.doi.org/10.1111/j.1467-646X.2010.01037.x

Ding, Y., Hope, O-K., Jeanjean, T., \& Stolowy, H. (2007). Differences between domestic accounting standards and IAS: Measurement, determinants and implications. Journal of Accounting \& Public Policy, 26, 1-38. http://dx.doi.org/10.1016/j.jaccpubpol.2006.11.001

Ettredge M.L., Soo Young K, Smith D.B., \& Zarowin, P.A. (2005). The impact of SFAS No. 131 business segment data on the market's ability to anticipate future earnings, The Accounting Review, 80(3), 773-804. http://dx.doi.org/10.2308/accr.2005.80.3.773

Flamholtz, E. (1999). Human Resource Accounting: Advances in Concepts, Methods, and Applications, 3rd Ed. Boston, MA: Kluwer Academic Publishers. http://dx.doi.org/10.1007/978-1-4615-6399-0

Flamholtz, E., Bullen, M.L. \& Hua, W. (2002). Human resource accounting: a historical perspective and future implications, Management Decision, 40(2), 947-954. http://dx.doi.org/10.1108/00251740210452818

Gamerschlag, R. (2013). Value relevance of human capital information. Journal of Intellectual Capital, 14(2), 325-345. http://dx.doi.org/10.1108/14691931311323913

Goodwin, J., Ahmed, K., \& Heaney, R. (2008), The effects of international financial reporting standards on the accounts and accounting quality of Australian firms: a retrospective study. Journal of Contemporary Accounting \& Economics, 4(2), 89-119. http://dx.doi.org/10.1016/S1815-5669(10)70031-X

Hassel, L., Nilsson, H. \& Nyquist, S. (2005). The value relevance of environmental performance. European Accounting Review. 14(1), 41-61. http://dx.doi.org/10.1080/0963818042000279722

Hayn, C. (1995). The information content of losses, Journal of Accounting \& Economics, 20(2), 125-53. http://dx.doi.org/10.1016/0165-4101(95)00397-2

Healy, P., \& Palepu, K. (2001). Information asymmetry, corporate disclosure, and the capital markets: A review of the empirical disclosure literature. Journal of Accounting \& Economics, 31(1-3), 405-444. http://dx.doi.org/10.1016/S0165-4101(01)00018-0

Horton, J., Serafeim, G., \& I. Serafeim (2011). Does mandatory IFRS adoption improve the information environment? Contemporary Accounting Research, 30(1), 388-423. http://dx.doi.org/10.1111/j.1911-3846.2012.01159.x

Kim, J-B., \& Shi, H. (2010). International Financial Reporting Standards, institutional infrastructures, and cost of equity capital around the World. Working paper, City University of Hong Kong and Fudan University.

Kim, J-B., \& Shi, H. (2012). Voluntary IFRS adoption, analyst coverage and information quality: International evidence. Journal of International Accounting Research, 11(1), 45-76. http://dx.doi.org/10.2308/jiar-10216

Kothari, S.P., \& Zimmerman, J.L. (1995). Price and return models. Journal of Accounting and economics, 20(2), 155-192. http://dx.doi.org/10.1016/0165-4101(95)00399-4 
Lajili, K., \& Zeghal, D. (2005). Labor cost voluntary disclosures and firm equity values: Is human capital information value-relevant? International Journal of Accounting, Auditing \& Taxation, 14(2), 121-138. http://dx.doi.org/10.1016/j.intaccaudtax.2005.08.003

Lajili, K., \& Zeghal, D. (2006), Market performance impacts of human capital disclosures. Journal of Accounting \& Public Policy, 25(2), 171-194. http://dx.doi.org/10.1016/j.jaccpubpol.2006.01.006

Lapointe-Antunes, P., Cormier, D., Magnan, M., \& Gay-Angers, S. (2006). On the relationship between voluntary disclosure, earnings, smoothing and value-relevance of earnings: The case of Switzerland. European Accounting Review, 15(4), 465-505. http://dx.doi.org/10.1080/09638180601102040

La Porta, R., Lopez-de-Silanes, F., Shleifer, A., \& Vishny, R. (1997). Legal determinants of external finance. Journal of Finance, 52(3), 1131-1150. http://dx.doi.org/10.1111/j.1540-6261.1997.tb02727.x

Leuz, C., \& Verrecchia, R.E. (2000). The economic consequences of increased disclosure. Journal of Accounting Research, 38, 91-124. http://dx.doi.org/10.2307/2672910

Lev, B. (2001). Intangibles: Management, measurement, and reporting. Washington, DC: The Brookings Institution.

Lev, B., \& Sougiannis, T. (1996). The capitalization, amortization, and value-relevance of R\&D. Journal of Accounting \& Economics, 21, 107-138. http://dx.doi.org/10.1016/0165-4101(95)00410-6

McKinsey (2002). Emerging Market Policy Maker Opinion Survey on Corporate Governance. McKinsey.

Nobes, C. \& Parker, R. (2008). Comparative International Accounting, Harlow: Pearson Education Limited.

Ohlson, J. (1995). Earnings, book values and dividends in security valuation, Contemporary Accounting Research. 11(2), 661-687. http://dx.doi.org/10.1111/j.1911-3846.1995.tb00461.x

Oliveira, L., Rodrigues, L. \& Craig, R. (2010). Intangible assets and value relevance: Evidence from the Portuguese stock exchange. The British Accounting Review, 42(4), 241-252. http://dx.doi.org/10.1016/j.bar.2010.08.001

Samudhram, A., Shanmugam, B. \& Low, K. (2008). Valuing human resources: An analytical framework. Journal of Intellectual Capital, 9(4), 655-667. http://dx.doi.org/10.1108/14691930810913203

Samudhram, A, Stewart, E, Wickramanayake, J. \& Sinnakkannu, J. (2014). Value relevance of human capital based disclosures: Moderating effects of labor productivity, investor sentiment, analyst coverage and audit quality. Advances in Accounting, 30, 338-353. http://dx.doi.org/10.1016/j.adiac.2014.09.012

Stock, J. H., \&Watson, M.W. (2011). Introduction to econometrics (3rd ed.): Prentice Hall.

United Nations Conference on Trade and Development (UNCTAD). (2008). 2007 Review of the Implementation Status of Corporate Governance Disclosures: Case Study of Egypt. In International accounting and reporting issues, 2007 Review. New York, NY: United Nations.

Vafaei, A., Taylor, D., \& Ahmed, K. (2011). The value relevance of intellectual capital disclosures. Journal of Intellectual Capital, 12(3), 407-429. http://dx.doi.org/10.1108/14691931111154715

Van der Meer-Kooistra, J., \& Zijlstra, S. (2001). Reporting on intellectual capital. Accounting, Auditing \& Accountability Journal, 14(4), 456-476. http://dx.doi.org/10.1108/09513570110403461

Verma, S. \& Dewe, P. (2004). Valuing human resources, ACCA Report.

Verma, S. \& Dewe, P. (2008). Valuing human resources: Perceptions and practices in UK organizations. Journal of Human Resource Costing \& Accounting, 12(2), 102-123. http://dx.doi.org/10.1108/14013380810889547

Wu, J. S., \& Zhang, I. X. (2009). The voluntary adoption of internationally recognized accounting standards and firm internal performance evaluation. The Accounting Review, 84(4), 1281-1309. http://dx.doi.org/10.2308/accr.2009.84.4.1281

World Bank. (2002). Report on the observance of standards and codes, Accounting and Auditing: Arab Republic of Egypt. New York, NY: World Bank.

World Bank. (2004). Report on the observance of standards and codes, Corporate governance country assessment: Arab Republic of Egypt. New York, NY: World Bank.

Wyatt, A. (2008). What financial and non-financial information on intangibles is value-relevant? A review of the evidence. Accounting and Business Research, 38(3), 217-256. http://dx.doi.org/10.1080/00014788.2008.9663336 


\section{Notes}

Note 1. The measure of labor cost used in this study is based on Lajili and Zeghal (2005) and Samudhram et al. (2014), who use the total employee costs per year as the proxy for firm-level human capital quality. This proxy is widely used in studies that use cost-based models to measure human capital (Flamholtz, 1999). In this study, the natural $\log$ of labor costs is used instead to recognize the non-normally distributed nature of these costs.

Note 2. Following Core et al. (2003), stock price is measured as the closing price 120 days after the fiscal year-end date in order to permit available information to be fully impounded into price.

Note 3. The choice of model specification largely follows from the research question (Kothari and Zimmerman, 1995). Price models show the value relevance effects of labor costs, while return models show the whether banks conducting changes in labor costs experience changes in value during the time period when labor cost changes are disclosed. To present a complete analysis of the value relevance of labor costs and to enhance comparison to other studies, both price (e.g., Sang and Dennis, 2014) and return model (e.g., Armstrong et al., 2010) specifications are estimated.

Note 4. Devalle et al. (2010) suggests that a fixed effects model is required when the covariates and unobservable non-time-varying characteristics correlate.

Appendix A: Variable definitions

\begin{tabular}{|c|c|}
\hline Variable & Definition (Source: Compustat Global file, except analyst coverage data) \\
\hline (Stock) & $\begin{array}{l}\text { One of two value relevance measures: stock price (PRICE) or returns }(R E T U R N S) \text {. PRICE is the } \\
\text { natural logarithm of bank } i \text { 's closing stock price } 4 \text { months after the end of fiscal year } t ; \text {; RETURN is } \\
\text { the annual return on bank } i \text { 's stock measured } 4 \text { months after the end of fiscal year } t \text {. }\end{array}$ \\
\hline$L B R$ & $\begin{array}{l}\text { Natural logarithm of total labor costs (Compustat mnemonic: LBR) scaled by total number of } \\
\text { common shares outstanding (Compustat mnemonic: CSHOI). }\end{array}$ \\
\hline IFRS & Dummy variable coded as 1 for fiscal years starting on or after January 1, 2005, and 0 otherwise; \\
\hline$L B R * I F R S$ & Two-way interaction term representing labor costs reported by mandatory IFRS adopters only \\
\hline VOL & $\begin{array}{l}\text { Dummy variable referring to the status of bank } i \text { as a voluntary IFRS adopter, coded } 1 \text { if the set of } \\
\text { accounting standards (Compustat mnemonic: ACCTSTD) followed by bank } i \text { before the official } \\
\text { date of mandatory IFRS adoption was "DI", "DA", or "DT" and } 0 \text { otherwise, where "DA" } \\
\text { represents domestic standards generally in accordance with IASC and OECD (Organization for } \\
\text { Economic Cooperation and Development), "DI" represents domestic standards generally in } \\
\text { accordance with IASC, and "DT" represents domestic standards in accordance with principles } \\
\text { generally accepted in the United States and generally in accordance with IASC and OECD } \\
\text { guidance. }\end{array}$ \\
\hline PREDUM & $\begin{array}{l}\text { Dummy variable coded } 1 \text { if the observation pertains to the fiscal year before IFRS adoption in } \\
\text { January } 1,2005 \text {, and } 0 \text { if on or after that date. }\end{array}$ \\
\hline$L B R * V O L$ & Two-way interaction term representing labor costs reported by voluntary IFRS adopters only. \\
\hline VOL*PREDUM & $\begin{array}{l}\text { Two-way interaction term representing banks voluntarily adopting IFRS prior to mandatory } \\
\text { adoption date. }\end{array}$ \\
\hline$L B R^{*} P R E D U M$ & Two-way interaction term representing labor costs reported prior to mandatory IFRS adoption date. \\
\hline$L B R * V O L * P R E D U M$ & $\begin{array}{l}\text { Three-way interaction term representing labor costs of voluntary IFRS adopting bank } i \text { in } \\
\text { pre-mandatory IFRS adoption year } t \text {; }\end{array}$ \\
\hline$B V$ & Book value of total equity at year-end. \\
\hline$E A R N$ & Earnings before interest and taxes, after adding back LBR. \\
\hline SIZE & Bank size: computed as the natural log of book value of assets at year-end. \\
\hline$L V G$ & Leverage; computed as the ratio of total liabilities to total assets at year-end. \\
\hline GRO & $\begin{array}{l}\text { Sales growth, computed as the ratio of the difference between current and previous year's sales } \\
\text { (Compustat mnemonic: SALE), to previous year's sales. }\end{array}$ \\
\hline$N E R N$ & $\begin{array}{l}\text { Incidence of negative earnings, coded as } 1 \text { if income before extraordinary income is negative and } 0 \\
\text { otherwise. }\end{array}$ \\
\hline$C V G$ & $\begin{array}{l}\text { Analyst coverage, computed as sum of the number of analyst recommendations issued to a bank } \\
\text { during the year (source; } I / \mathrm{B} / \mathrm{E} / \mathrm{S} \text { ). }\end{array}$ \\
\hline$Y_{D}$ and $C_{D}$ & Year and country fixed effects, respectively. \\
\hline$\delta_{i t}, e_{\mathrm{it}}, \zeta_{\mathrm{it}}$ & Error term. \\
\hline
\end{tabular}

